\title{
Environments and Cultural Change in the Indian Subcontinent
}

\section{Implications for the Dispersal of Homo sapiens in the Late Pleistocene}

\author{
by James Blinkhorn and Michael D. Petraglia
}

\begin{abstract}
The Indian subcontinent lies on a key east-west corridor for hominin expansions across Asia, which has led to it playing a prominent role in debate surrounding the dispersal of modern humans. The current geography and ecology of the region consists of a diverse array of habitats. An examination of changes in monsoonal intensity indicates that geographic reconfiguration of ecological diversity occurred, but at a regional level, South Asia is shown to provide suitable environments for hominin occupations throughout the Late Pleistocene. Unfortunately, the fossil record of South Asia remains poor, preventing decisive resolution of modern human dispersal debates. However, in the past decade new interdisciplinary approaches to the archaeological record have overhauled the framework for understanding behavioral change during the Late Pleistocene. While the nature of the Late Acheulean to Middle Paleolithic transition remains to be resolved, it is now clear that it appears significantly later than in other Old World regions and may coincide with the expansion of modern humans across Asia. Mounting evidence supports a gradual rather than abrupt transition from Middle to Late Paleolithic technologies, which does not easily reconcile with arguments for the introduction of microlithic tool kits by the earliest expansions of modern humans.
\end{abstract}

The Late Pleistocene record of Asia is marked by significant changes in human demography and behavior, including, most notably, the expansion of Homo sapiens from Africa (Athreya 2015; Barker et al. 2007; Demeter et al. 2012; Grun et al. 2005; Kennedy and Deraniyagala 1989; Liu et al. 2015; Mijares et al. 2010) and their interbreeding with archaic populations (Green et al. 2010; Kuhlwilm et al. 2016; Nielsen et al. 2017; Prüfer et al. 2014; Rasmussen et al. 2011; Reich et al. 2010). The Indian subcontinent is a critical region to explore human dispersals because of its geographic position on major east-west routes of human migration across Asia (e.g., Boivin et al. 2013; Petraglia et al. 2010; Reyes-Centeno et al. 2014). Yet the complexities of the archaeological record of the Indian subcontinent have historically been overlooked in grand, sweeping narratives of human expansion (e.g., Oppenheimer 2012; Stringer 2000).

James Blinkhorn is Research Associate in the Department of Archaeology, Classics, and Egyptology at the University of Liverpool (12-14 Abercromby Square, Liverpool L69 7WZ, United Kingdom [j.blinkhorn@liverpool.ac.uk]) and at the Max Planck Institute for the Science of Human History (Kahlaische Strasse 10, D-07743 Jena, Germany). Michael D. Petraglia is Professor at the Max Planck Institute for the Science of Human History (Kahlaische Strasse 10, D-07743 Jena, Germany [petraglia@shh.mpg.de]). This paper was submitted 12 X 16, accepted 15 VI 17, and electronically published $23 \times 17$.
For much of the twentieth century, incremental advancement of technology in the South Asian Paleolithic was accepted as part of the gradual, regional evolution of human populations (e.g., Misra 1989). In the past several decades, however, a growing body of biomolecular evidence has clearly indicated that all living populations shared a recent and common African ancestry, focusing debate on how and when modern humans first left Africa (Cann, Stoneking, and Wilson 1987; Harpending et al. 1993; Stoneking 1989). In light of a stark change in population, a hunt was triggered to identify a similarly sharp change in the behavioral record of the Indian subcontinent echoing the Upper Paleolithic "revolution" of Western Europe (Misra in Agrawal and Ghosh 1973; James and Petraglia 2005). Contemporary analyses support an African origin of our species, but it is now clear that dispersing populations of modern humans interbred with local archaic populations across Eurasia (see Nielsen et al. 2017). Recent research indicates that South Asian populations preserve a relatively high proportion of Denisovan DNA compared with other Eurasian populations, which has implications for understanding the number, timing, and geography of interbreeding episodes (Sankarararman et al. 2016). This more complex demographic scenario is accompanied by wider awareness of the diverse factors that influence cultural evolution and technological innovation (e.g., Collard, Buchanan, and O’Brien 2013; Grove 2015; Vaesen et al. 2016).

Major changes in our understanding of the Late Pleistocene hominin occupation of the Indian subcontinent have resulted 
from interdisciplinary research projects implemented over the last decade and particularly the application of chronometric dating methods (see below). Better dating controls have led to new explanations for when major changes occurred in technological and cultural developments. In particular, current debate centers on two key issues: (1) whether technological continuities occur between Late Acheulean and Middle Paleolithic industries (Mishra, Chauhan, and Singhvi 2013) or between Middle and Late Paleolithic industries (Petraglia et al. 2009, 2012), and (2) whether modern humans first arrived in South Asia using Middle Paleolithic technologies (Blinkhorn et al. 2013; Clarkson, Jones, and Harris 2012; Petraglia et al. 2007) or Late Paleolithic technologies (Mellars 2006; Mellars et al. 2013; Mishra, Chauhan, and Singhvi 2013). Here, we review the current body of evidence for Late Pleistocene occupation of the Indian subcontinent and reexamine what impli- cations these discoveries have for understanding technological change, human expansions, and hominin admixture.

\section{Geographic Context}

The Indian subcontinent broadly corresponds with the political region of South Asia (Bangladesh, Bhutan, India, Nepal, Pakistan, and Sri Lanka). Continental borders with surrounding regions are characterized by high-relief mountain chains and plateaus, such as the Hindu Kush, the Himalaya, and the Patkai ranges (fig. 1), which are the orogenic product of the collision of the Indian and Eurasian tectonic plates (van Hinsbergen et al. 2012). It is within these extreme high-relief borders to the region that the source for the three largest river systems of the subcontinent - the Indus, the Ganges, and the Brahmaputra - are to be found. Within the subcontinent, a number of smaller

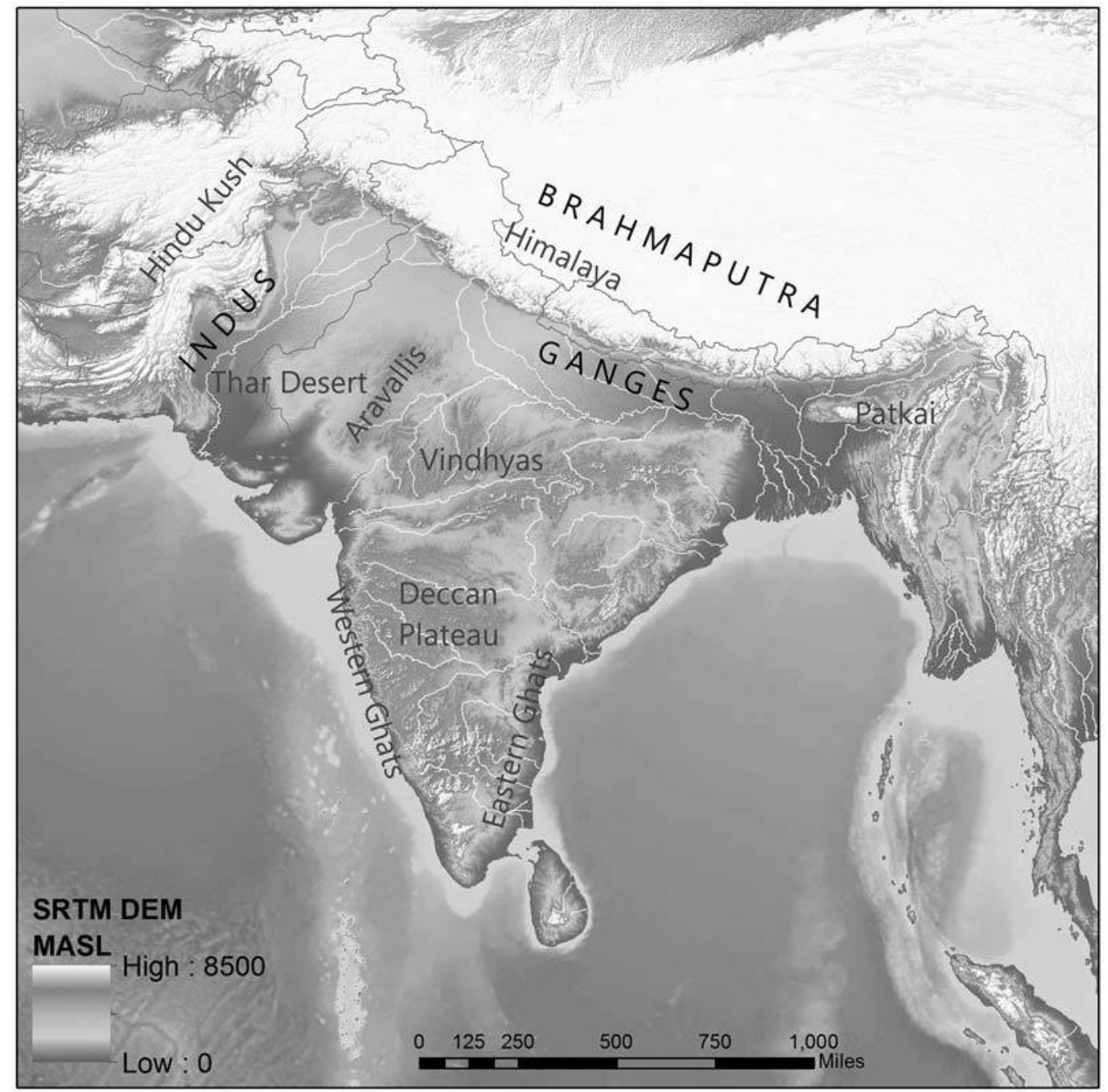

Figure 1. Digital elevation model of the Indian subcontinent (US Geological Survey 2006). The subcontinent's broad, low-relief fluvial network stands in stark contrast to the extreme topography found to the west, north, and east. A color version of this figure is available online. 
mountain ranges and elevated plateaus are also present, including the Aravalli and Vindhyan ranges, the Western and Eastern Ghats, and the Deccan Plateau. These provide the source for other major fluvial systems, such as the Narmada, that drain westward from the Vindhyas and the Godavari, Krishna, and Kaveri rivers that drain eastward across the Deccan Plateau and Eastern Ghats.

The stepwise uplift of the Tibetan Plateau and surrounding mountain ranges has also played a defining role in the evolution of the dominant environmental feature of the Indian subcontinent: the monsoon (Molnar, England, and Martinod 1993; Zhisheng 2001). The monsoon system is driven by a cross equatorial atmospheric pressure gradient resulting from differential heating of the Asian landmass, principally the Tibetan Plateau, and the Mascarene high-pressure zone in the southern Indian Ocean (Clemens et al. 1991; Gadgil 2003; Leuschner and Sirocko 2003). Strong southwesterly winds occur during the summer months, delivering the majority of the subcontinent's precipitation following evaporation from the Arabian Sea, whereas weaker and regionally restricted northeasterly winds deliver more limited precipitation during the winter months (Clemens et al. 1991; Gadgil 2003; Leuschner and Sirocko 2003). Recent stepwise tectonic uplift $~ 150$ ka was localized in the northeast Tibetan Plateau and is unlikely to have significantly affected the South Asian monsoon ( $\mathrm{Li}$ et al. 2014). However, the increased aridification of the Asian interior that resulted from this may have altered the importance of the habitable landscapes in South Asia for hominins.

Although the effects of the monsoons are felt across the Indian subcontinent, the distribution of precipitation is distinctly regional and highly seasonal. Yet beyond relief, the geological structure of the Indian subcontinent plays another important role in patterns of habitability in the region. The analysis of the structure of geological basins within the Indian subcontinent led Korisettar (2007) to the conclusion that the Purana basins exerted a strong influence on hominin dispersals and occupation history. Although direct precipitation within the Purana basins is lower than other regions of the subcontinent, perennial supplies of freshwater are available because of spring activity from aquifers that deliver water resources from regions that receive much higher monsoonal precipitation. As a result of reliable water resources and abundant raw materials for stone tool manufacture, these geological basins are thought to have acted as refugia not only for hominin populations but also for varied flora and fauna (Korisettar 2007).

The importance of such Purana basins for providing refugia is well exemplified by the recent study of fauna from the Billasurgum caves, located within the Cuddapah Basin. Here, excavations revealed the first stratified sequence to document patterns of faunal occupation spanning the late Middle Pleistocene to Late Pleistocene (Roberts et al. 2014). This study illustrated the long-term continuity of large-bodied fauna within South Asia with only a single taxon of twenty-four identified as having gone extinct across the subcontinent (Roberts et al. 2014). Patterns of environmental change throughout the Late Pleisto- cene are likely to have resulted in the significant redistribution of South Asia's habitats. However, the broad ecological mosaic of the region appears to have buffered such changes, helping to prevent widespread megafaunal extinctions as observed elsewhere in the world (e.g., Koch and Barnosky 2006).

\section{Environmental Context}

The modern environments of the Indian subcontinent are diverse and sustain over a sixth of the world's current human population (United Nations Department of Economic and Social Affairs and Population Division 2015) in a mosaic of deserts and tropical rainforests, alpine tundra and savannahs, and subtropical woodland and mangroves, and riparian corridors (Mani 2012; fig. 2). Given the region's latitude, South Asia is subject to warm temperatures with limited seasonal change. This stands in stark contrast to regions immediately to the north and west, where high-amplitude temperature change can be observed both daily and seasonally. Fluctuating humidity, controlled primarily by monsoonal intensity, provides the more significant climatic factor that may have influenced habitat distribution and hominin demography across South Asia during the Late Pleistocene.

Variability within Pleistocene monsoonal circulation patterns must be considered in the context of interhemispherical oceanic and atmospheric interactions (Wang et al. 2005). Increases in solar insolation, predominately due to $19,000-23,000$-year precessional cycles, result in the northward movement of the InterTropical Convergence Zone (ITCZ) because of raised sea surface temperatures at low latitudes (Yi et al. 2012). The northward movement of the ITCZ results in increased monsoonal circulation capable of delivering a greater level of precipitation. Maximum global ice volumes, which are dominated by $\sim 100,000$-year cycles, may modulate monsoonal circulation by reducing sea surface temperatures and sea levels, altering the availability of water vapor for precipitation (Guo et al. 2002; 2004). Global ice volume variability and differences between hemispheres may also affect the heat differential and moisture availability between the ocean and land that drives monsoonal circulation because of an increased continental surface (Wang 1999). Studies of monsoonal intensity over the past million years indicate that monsoonal minima rarely coincide with glacial maxima due to differences in patterns in glaciation at the poles (Caley et al. 2013; Liu et al. 2011; Zhisheng et al. 2011). As a result, an examination of patterns of climatic change over the Late Pleistocene in South Asia must combine both high- and low-latitude archives of paleoenvironmental variability.

In figure 3, we combine data from Bittoo Cave, northwest India (Kathayat et al. 2016), a Bay of Bengal marine core (Site 758; Bolton et al. 2013), and two Arabian Sea marine cores (MD042861, Caley et al. 2011; Owen Ridge, Clemens and Prell 2003), as local proxies for summer monsoon intensity, with Arctic (SPECMAP, Imbrie et al. 1984) and Antarctic (Vostok, Petit et al. 1999) oxygen isotope records to present both the regional and global context of climate change over the past $350 \mathrm{ka}$. 

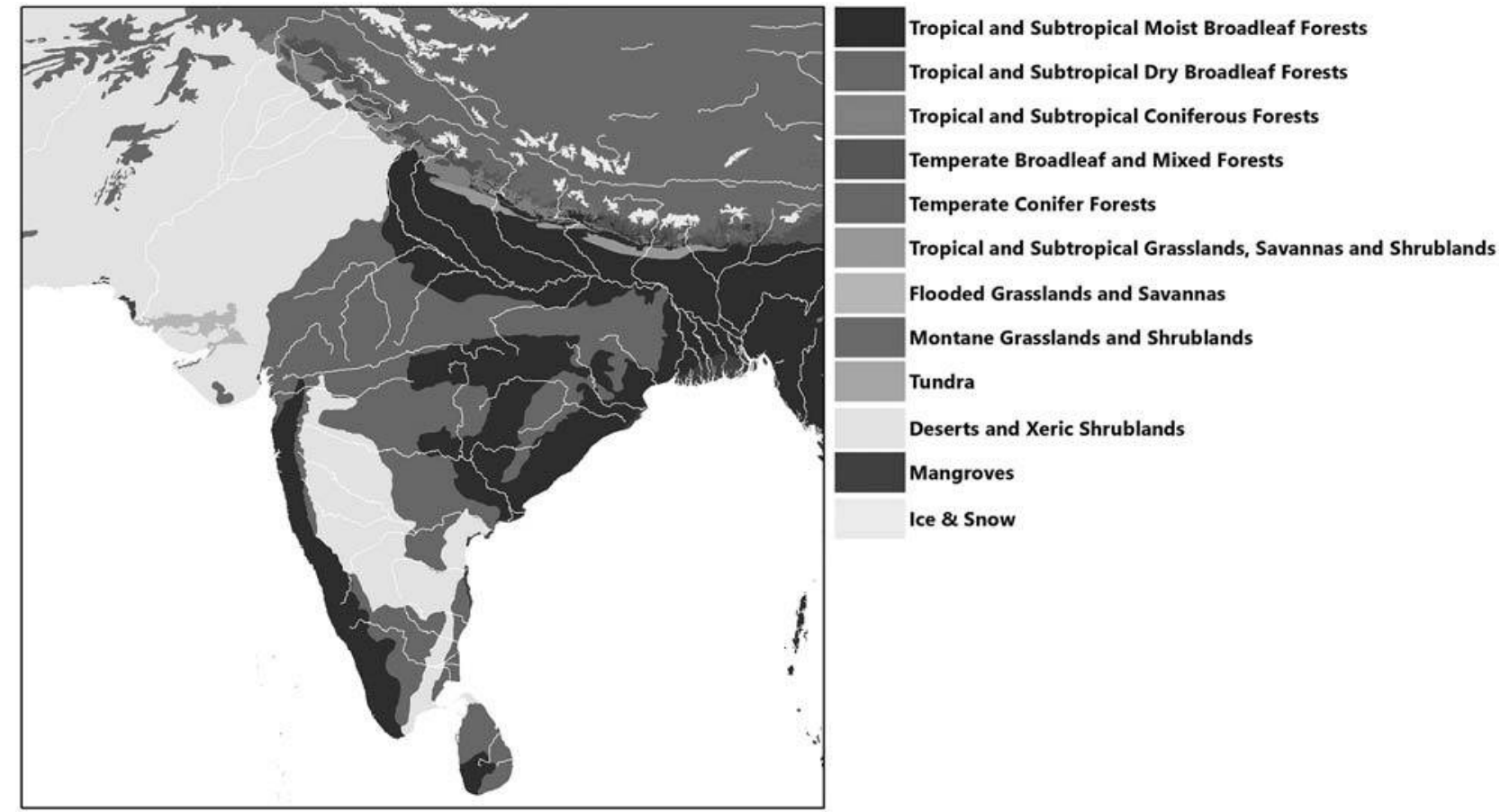

Figure 2. Map of modern ecology within the Indian subcontinent (following Olson et al. 2001) illustrating a mosaic of dry shrubland, tropical grassland, and forest habitats in contrast to the exclusively arid habitats to the west, montane grasslands to the north, and tropical forests to the east. A color version of this figure is available online.

Although in this paper we review behavioral evidence for the past $140 \mathrm{ka}$, the paleoenvironmental records illustrated in figure 3 indicate a number of differences over longer time frames that may be relevant to broader questions regarding Asian hominin demography throughout the Pleistocene. Most critically, peaks of monsoonal intensity can be repeatedly observed during glacial phases that match those present in interglacial phases. Marine isotope stages (MIS) often provide a useful means for organizing discussion of changing human behavior through time and indeed do so at an appropriate scale for the resolution of the South Asia archaeological record and so are used below. However, as the resolution of the archaeological data improves, it is anticipated that reference to global events, such as Heinrich events, or regional variability in monsoon intensity will become critical. Below we describe the key trends in monsoonal intensity for the Late Pleistocene identified in proxy data sets presented in figure 3.

At the end of MIS $6(\sim 140-150 \mathrm{ka})$, proxies of monsoonal intensity indicate a period in which peaks of monsoon activity match the scale observed during interglacial conditions, which is particularly evident in the Site 758 Bay of Bengal records. However, a sharp decline in monsoonal intensity follows this period that approaches the scale of other Middle Pleistocene monsoonal minima, evident in the records at Bittoo and MD042861. The advent of interglacial conditions in MIS 5 (71-130 ka) sees the return of more intense monsoonal conditions. However, the four regional data sets indicate peak monsoonal intensity occurring during different phases: during MIS 5e (115-
$130 \mathrm{ka}$ ) in Owen Ridge, during MIS 5c (93-106 ka) in MD042861 and Bittoo, and during MIS5a (71-84 ka) in Site 758. All regional data sets presented in figure 3 indicate a sharp decline of monsoonal intensity correlated with MIS 4 (59-71 ka), with one Arabian Sea record suggesting lower monsoonal intensity than the last glacial maximum (LGM), and rivalling the penultimate glacial maximum $\sim 150 \mathrm{ka}$. The return of stronger monsoonal conditions is observable from the start of MIS 3 (28-59 ka) across all proxy records and in each case records peaks of monsoonal intensity that are close to or exceed peaks observed during MIS 5, particularly between $\sim 40$ and 59 ka. Records from Bittoo and MD04-2861 suggest that higher amplitude and frequency of oscillations in monsoonal intensity occur during this period, with all records displaying a gradual decline in monsoonal activity toward the end of MIS 3. With minima in monsoonal intensity observed in all records $\sim 21 \mathrm{ka}$, there is little evidence to suggest the monsoonal minimum significantly predates the LGM.

The availability and distribution of sufficient freshwater resources, largely relating to the intensity and geography of monsoonal precipitation, probably played a critical role in determining the spatial configuration of South Asia's diverse habitats and the viability of human occupation of the subcontinent. Figure 4 presents modeled distribution of precipitation for MIS 5e and the LGM (Braconnot et al. 2007; Otto-Bleisner et al. 2006). These offer useful analogies for the scale of variability of precipitation and its distribution between monsoonal minima and maxima identified above and in figure 3. Extreme 


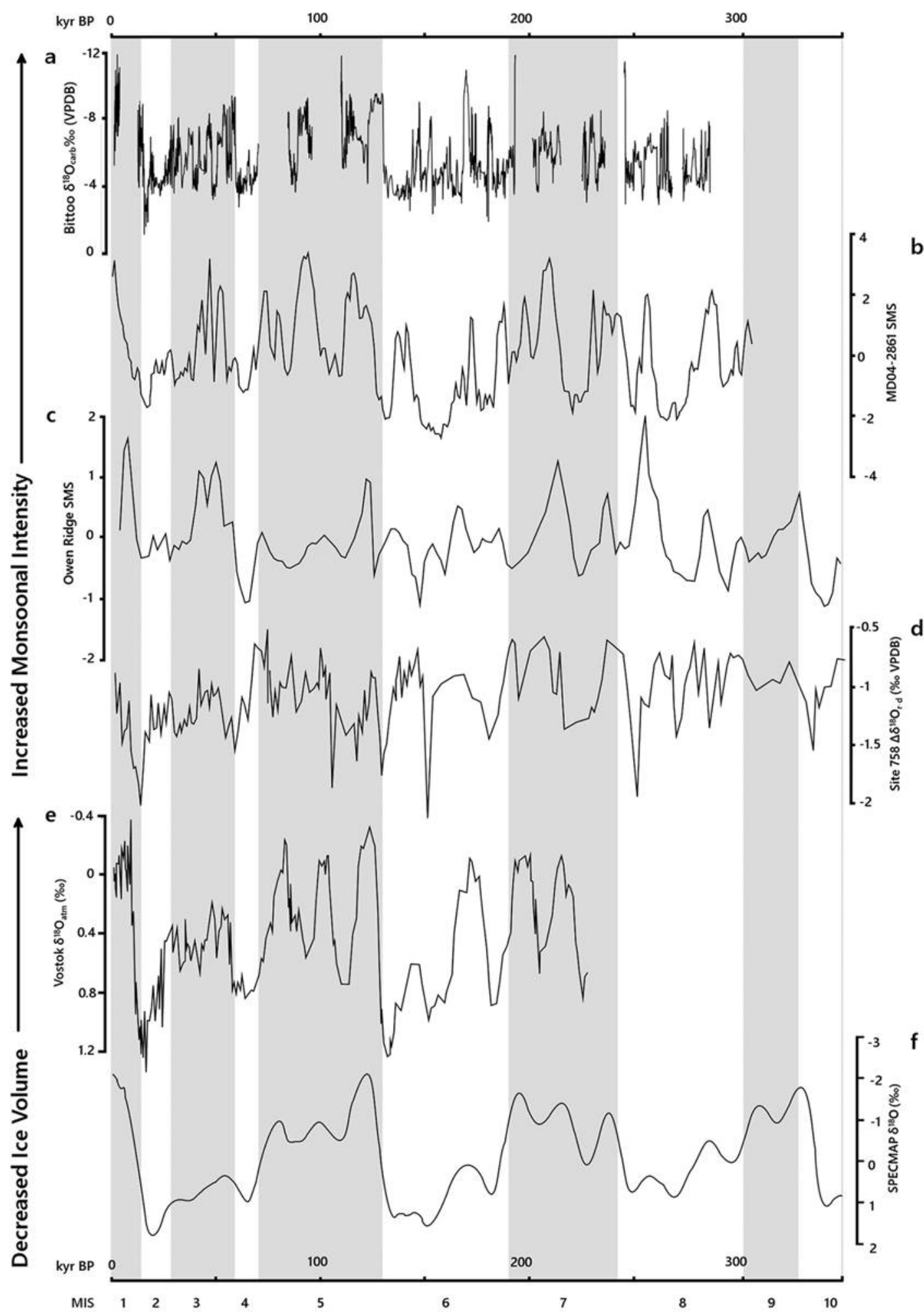

Figure 3. Four archives of environmental change in the Indian subcontinent, including oxygen isotope records from Bittoo Cave (a), two alternate summer monsoon stacks from the Arabian Sea (b, MD04-2861; $c$, Owen Ridge), and oxygen isotope records from Site 758, Bay of Bengal $(d)$, plotted with high-latitude southern (e, Vostok) and northern ( $f$, SPECMAP) oxygen isotope records spanning the past 350,000 years (modified from Bolton et al. 2013; Caley et al. 2011; Clemens and Prell 2003; Imbrie et al. 1984; Kathayat et al. 2016; Petit et al. 1999). Climatic archives from the Indian subcontinent illustrate different patterns of monsoonal intensity than are typically inferred from high-latitude records, which often provide the framework for discussing later Pleistocene environmental change globally and particularly the high monsoonal intensity observed during MIS 3.

This content downloaded from 194.094.206.187 on November 02, 2017 04:54:04 AM 


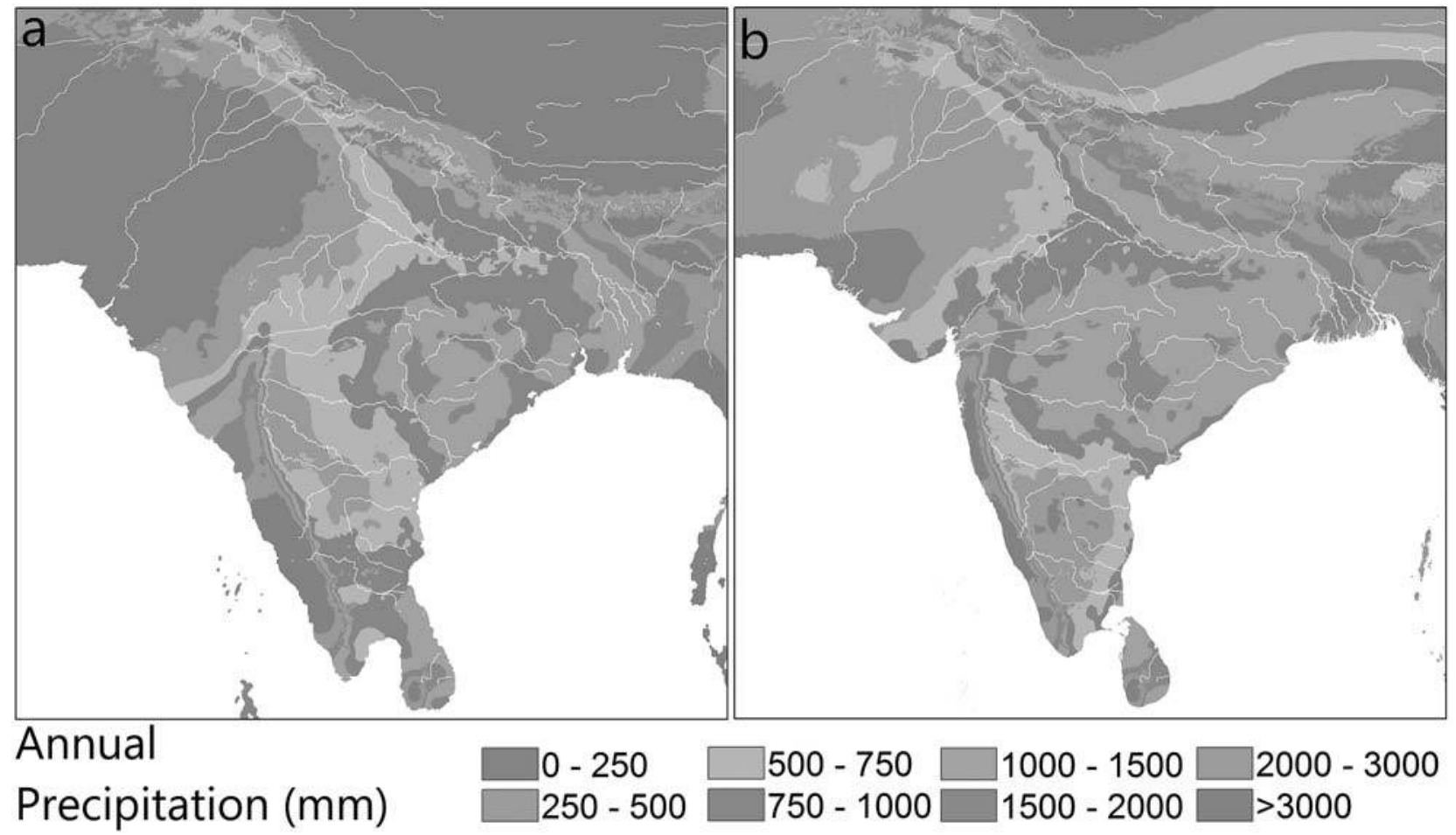

Figure 4. Precipitation models for the Indian subcontinent for the last glacial maximum ( $a$, following Braconnot et al. 2007) and marine isotope stage $5 \mathrm{e}(b$, following Otto-Bleissner et al. 2006), offering insight into the scale of change in precipitation between monsoonal minima and maxima, respectively. Notably, much of the subcontinent enjoys humidity within an ideal range for human inhabitation at both monsoonal minima and maxima. A color version of this figure is available online.

aridity ( $<200 \mathrm{~mm}$ annual precipitation) probably prevented occupation of the Thar Desert during suppressed monsoonal regimes. Although less prohibitive to human occupation, extreme levels of humidity ( $>2,000 \mathrm{~mm}$ annual precipitation) can be observed in the rain forests in northeastern regions of the Indian subcontinent, which may have demanded distinct biological and cultural strategies for humans to successfully adapt to these habitats (Roberts, Boivin, and Petraglia 2015). With these exceptions aside, the majority of the Indian subcontinent offers habitats that are not prohibitive to hominin habitation and indeed are likely to have offered ideal habitats for long-term occupation and expansion (see Finlayson 2013).

\section{The Hominin Fossil Record}

Limited change has occurred to the fossil record of hominins in South Asia over the past decade. The only reliable evidence for pre-Homo sapiens anatomy from the Indian subcontinent remains the Hathnora specimen, a calvarium recovered from gravel deposits in the Narmada Valley (Sonakia and Kennedy 1985). While appearing distinctly archaic given the thickness of cranial bone, the specimen presents derived traits, such as a globular cranium, as well as a cranial capacity matching contemporaneous populations (Athreya 2015; Rightmire 2015). Attributing this specimen to any existing taxa appears prob- lematic, particularly as the specimen presents a mosaic morphology rather than distinctly African, West Eurasian, or East Eurasian traits (Athreya 2015). Although dating the specimen is problematic, the most secure age estimate is $\sim 236 \mathrm{ka}$, with ongoing surveys in the region aiming to bolster the fossil record and better understand the sedimentary context from which the Hathnora specimen was recovered (Cameron, Patnaik, and Sahni 2004; Kennedy 2000; Patnaik et al. 2009). Recent evidence for pre-sapiens populations (Sankhyan 2013) has been critiqued for the lack of diagnostic elements to firmly attribute the specimens as being hominin compounded by the absence of clear stratigraphic provenance or chronometric dating (Chauhan, Ozarkar, and Kulkarni 2015).

Similarly, little has changed in the fossil record for the appearance of Homo sapiens in the Indian subcontinent, with the earliest well-dated specimens significantly postdating the arrival of modern humans across the Old World. A skull that is suggested to retain archaic features comparable to Asian Homo erectus has recently been reported from sediments dating between 30 and $50 \mathrm{ka}$ in the Orsang Valley, western India, but direct dating of the specimen to the mid-Holocene complicates interpretation (Chamyal et al. 2011). The earliest definitive specimens of $H$. sapiens remain those from the cave sites of Fa Hien and Batadomba-Lena (see below) in Sri Lanka, appearing from $\sim 36$ to 28 ka onward (Deraniyagala 1992; Kennedy and Deraniyagala 1989; Perera et al. 2011). Within the 
past decade, four burned cranial vault fragments and a single tooth were recovered from a horizon dating to $12-20 \mathrm{ka}$ at Jwalapuram 9, which are the oldest $H$. sapiens specimens from mainland South Asia at present (Clarkson et al. 2009). Other sites within and adjacent to South Asia, such as Bhimbetka (India), present modern human specimens with some archaic features (Athreya 2015). Interpreting the meaning of this morphological diversity is complicated by the absence of reliable ages or certain associations with cultural deposits (Athreya 2015).

\section{The Archaeological Record}

The Indian subcontinent has a long history of Paleolithic research leading to the identification of numerous Late Pleistocene archaeological sites (Misra 2001; Pal 2002; Raju and Venkatasubbaiah 2002). Here, we will use the terms Late Acheulean, Middle Paleolithic, and Late Paleolithic to describe the three main Middle and Late Pleistocene Paleolithic industries following James and Petraglia (2005). This broadly relates to the production of bifaces and limited flake tools (Late Acheulean), the use of hierarchically prepared cores to produce predetermined blanks for more diverse flake tools (Middle Paleolithic), and microlithic/microblade-based industries showing some variation, such as the presence of prepared cores (Late Paleolithic). In the past, significant continuity has been identified between these technological phases. However, the general lack of dated sites with controlled understanding of assemblage formation processes may have served to blur the boundaries between industries. Poor chronometric controls and limited associations between fossil specimens and material culture have hampered critical assessment of behavioral changes associated with the arrival of Homo sapiens in South Asia.

Significant advances have been made in understanding the chronology of the Late Pleistocene archaeological record of South Asia in the past decade. The overall number of sites dated before the review presented by James and Petraglia (2005) was not insubstantial. However, the majority of these were Late Paleolithic sites dated by traditional radiocarbon methods, which is limited to the past $\sim 45$ thousand years. As a result, discussion of the tempo of behavioral changes, such as from the Middle to Late Paleolithic, has been problematic. The application of luminescence methods within the past decade has been critical for shedding light on the chronology of Middle Paleolithic occupations of the Indian subcontinent as well as establishing the lower age bounds of Late Acheulean occupations. Figure 5 presents a compilation of chronometric age estimates associated with Late Paleolithic, Middle Paleolithic, and Late Acheulean artefact assemblages dating between 20 and $140 \mathrm{ka}$ across South Asia. Below, we focus our review predominately on the results of the most recent programs of controlled excavations that have applied contemporary dating methods to present the most secure chronometric framework for cultural change in South Asia. However, it is worth noting few major discrepancies occur between this group and the wider corpus of dated sites presented in figure 5 .

\section{The Final Late Acheulean (Up to $100 \mathrm{ka}$ )}

Owing to new chronometric dating, it is now evident that the Late Acheulean of the Indian subcontinent includes some of the youngest occurrences of these industries worldwide. Recent research in the Middle Son Valley, north-central India, has constrained the youngest Late Acheulean assemblages. Excavations at the site of Bamburi 1 revealed a $4 \mathrm{~m}$ deep section including poorly sorted gravels and cobbles relating to the lower member of the Sihawal Formation and pedogenised sandy silts from the upper member of the Sihawal formation (Haslam et al. 2011). The interface of these two sediment units is constrained by three statistically indistinguishable optically stimulated luminescence (OSL) dates of $131 \pm 9 \mathrm{ka}$ (BAM3/2, Lower Member), $125 \pm 13 \mathrm{ka}(\mathrm{BAM} 1 / 2)$, and $131 \pm 10 \mathrm{ka}$ (BAM1/1, Upper Member; Haslam et al. 2011). The topmost deposits of the Lower Member yielded fresh examples of multiplatform and bifacially worked cores alongside a refined biface and are attributed to the Late Acheulean. Two dates from the Patpara Formation, which disconformably overlies the Sihawal Formation, of $137 \pm 10 \mathrm{ka}(\mathrm{PAT} 4 / 1)$ and $140 \pm 11 \mathrm{ka}$ (PAT3/2) are also associated with fresh Late Acheulean artefacts (Haslam et al. 2011). These dates correspond well with previous dating in the region, providing minimum ages for the Sihawal Formation to $>90 \pm 20 \mathrm{ka}(\mathrm{B}-1),>100 \mathrm{ka}(\mathrm{N}-1)$, and $>103.8 \pm$ 19.8 ka (Alpha 899; Pal et al. 2005; Williams and Clarke 1995; Williams et al. 2006). Critically, this research helps constrain the end of the Late Acheulean with maximum ages, whereas earlier studies on the youngest Late Acheulean in western and central India have only provided minimum ages (Ajithprasad 2005; Bednarik et al. 2005; Juyal et al. 2000).

\section{Middle Paleolithic (96-34 ka)}

Until recently, the time frame for the Middle Paleolithic was very poorly defined, based primarily on a small number of radiocarbon and uranium series dates that returned minimum ages. Preliminary studies at 16R Dune, in the Thar Desert in western India, indicated the presence of Middle Paleolithic technologies within contexts dating to $109 \mathrm{ka}$ (TL24) and 130 ka (TL19; Misra and Rajaguru 1989; Raghaven, Rajaguru, and Misra 1989; Singhvi et al. 2010). However, subsequent technological analysis by Gaillard (1993) failed to identify any artefacts among these assemblages that could securely be attributed to either Middle Paleolithic or Late Acheulean technologies.

Excavations at the site of Katoati, on the eastern margin of the Thar Desert, have identified a number of Middle Paleolithic assemblages (Blinkhorn et al. 2013), which currently include the oldest excavated and dated examples of this industry in South Asia. The archaeological horizons comprise deposits from the edge of a braided channel overlain by a cap of sand 


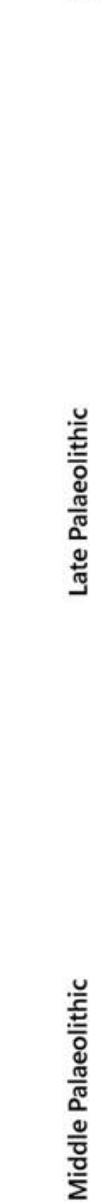

30

40

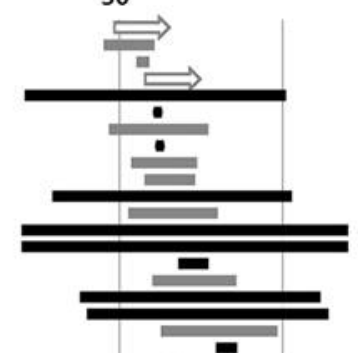

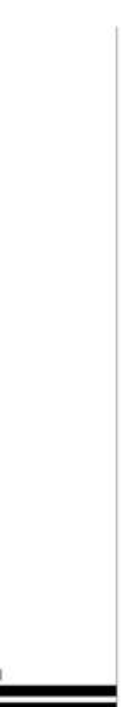

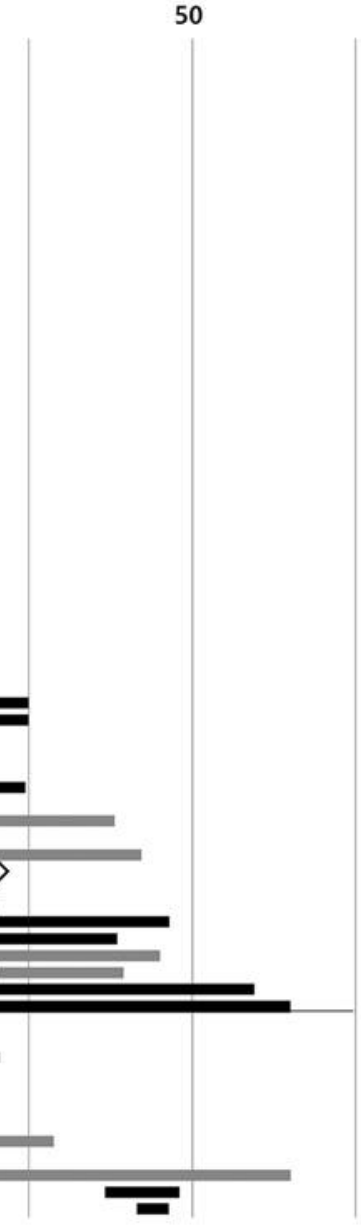

b

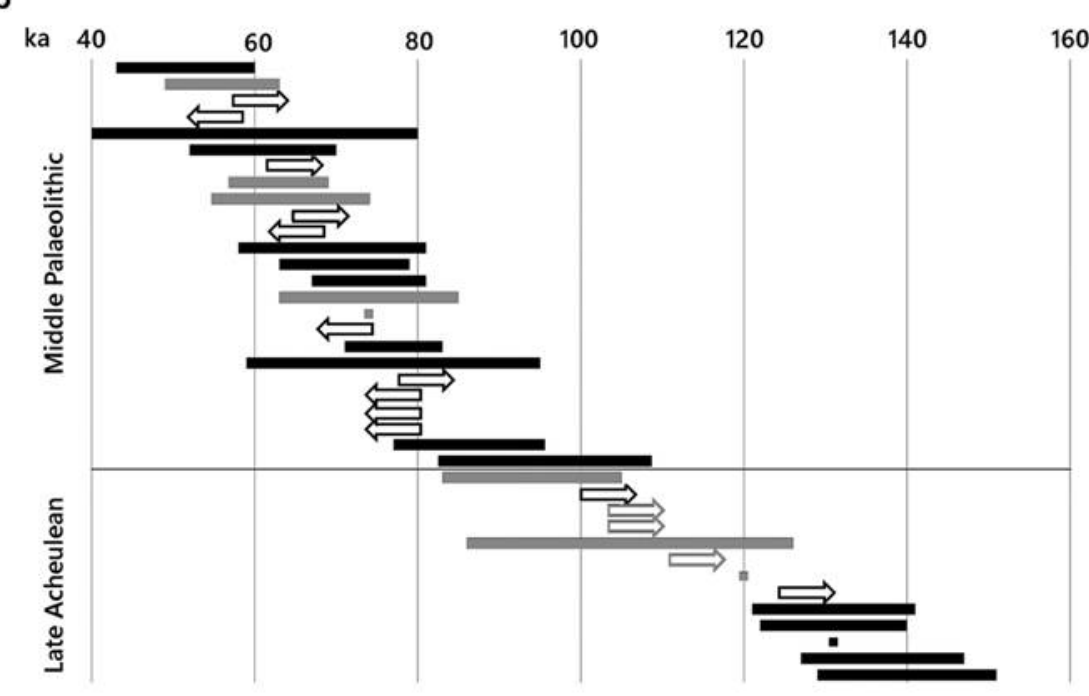

Figure 5. Age ranges for Late Pleistocene Paleolithic sites in South Asia where the central age estimate dates between 30 and 50 ka $(a)$ and 50 and $140 \mathrm{ka}(b)$. Arrows indicate minimum and maximum age estimates. Bars or arrows in black represent dated assemblages reported since 2007; bars or arrows in gray represent dated assemblages reported before 2007. Recent dating supports considerable chronological overlap between Middle and Late Paleolithic assemblages. The number of dated Middle Paleolithic assemblages has increased significantly in the past decade with the limited evidence for chronological overlap with Late Acheulean assemblages not supported by the most recent dating.

This content downloaded from 194.094.206.187 on November 02, 2017 04:54:04 AM 
dune deposits. Large proportions of the main assemblagesdating to $95.6 \pm 13.1 \mathrm{ka}$ (LD-1149), 96-77 ka, $77 \mathrm{ka}$ (LD1090 ), and $\sim 60 \mathrm{ka}$ - are composed of highly cortical simple cores and flakes. This probably represents a focus on primary reduction activities, exploiting the availability of cobbles made up of diverse materials associated with uplifted deposits from the Jayal Gravel ridge (Blinkhorn et al. 2017). Based on raw material types, only a single artefact can be identified as exotic to the site. Evidence for more formalized reduction strategies are evident in both the core and debitage assemblages, suggesting a focus on radial preparation of cores to remove large, broad flakes (Blinkhorn 2012). Similarly, a focus on point production is evident with the presence of prepared point cores analogous to Nubian core methods, Levallois and pseudoLevallois points, and retouching of flakes to produce convergent margins or basal modification (including shoulders, basal thinning, and a tang) to assist hafting of pointed flakes (Blinkhorn, Achyuthan, and Ajithprasad 2015).

Turning to southern India, sites from the Jurreru Valley also document patterns of Middle Paleolithic technological behavior during MIS 5. The site of Jwalapuram Locality 22 contains a large number of lithic artefacts recovered from a paleosol constrained by overlying deposits of YTT (74 ka) and an underlying OSL date of $\sim 85 \mathrm{ka}$ (J22/5; Haslam et al. 2012). At Jwalapuram Locality 3 , artefacts are found within a $\sim 25 \mathrm{~cm}$ thick pebbly horizon constrained by an underlying OSL age of $77 \pm$ $6 \mathrm{ka}$ (JLP-380) and an overlying deposit of primary YTT ash (Petraglia et al. 2007). Middle Paleolithic technologies at these sites include recurrent Levallois and discoidal core reduction methods alongside less formal single and multiplatform cores, a range of point forms (including Levallois points and single instances of unifacial, bifacial, and tanged points), retouched tools (predominately notches and scrapers), and notable proportions of blades, burins, and microblades (Clarkson, Jones, and Harris 2012). Paleoenvironmental work across the Jurreru Valley has indicated significant variability at a landscape scale that was preserved by a blanket of primary YTT ashfall. Isotopic and phytolith evidence indicates mixed $\mathrm{C}_{3}$ and $\mathrm{C}_{4}$ foliage with varying proportions depending on topographic position within the landscape and association with identifiable depositional centers (Blinkhorn et al. 2012).

Evidence for Middle Paleolithic assemblages in Sri Lanka predates sand dunes deposited between 74 and $64 \mathrm{ka}$ at Site 50 and appears in gravel deposits at Site 49, suggested to have been deposited in the early Upper Pleistocene (Deraniyagala 1992; Singhvi, Deraniyagala, and Sengupta1986). This finding is consistent with the appearance of Middle Paleolithic technology elsewhere in South Asia during MIS 5, but current descriptions of the technology do not enable comparative studies.

Besides Katoati, a number of sites in the Thar Desert preserve evidence of the Middle Paleolithic that postdate MIS 5. A new synthesis of the archaeological and chronometric evidence from 16R Dune suggests that a Middle Paleolithic occupation of the site is constrained by OSL dates of $80 \mathrm{ka}$ (TL13) and $40 \mathrm{ka}$ (TL11; Blinkhorn 2013). The artefact-bearing ho- rizon is found overlying the top of a number of carbonate layers, which form as postdepositional features over millennial time scales that are also bracketed by the OSL dates. As a result, it is suggested that this Middle Paleolithic occupation may be more closely associated with the younger end of this time bracket (Blinkhorn 2013). In addition to these excavations, artefact collections from Shergarh Tri Junction in the Thar Desert are attributed post quem dates of $60 \mathrm{ka}$ and $43 \mathrm{ka}$ (Blinkhorn 2014). Among the smaller collection dating to $<43 \mathrm{ka}$ are numerous cores with bidirectional blade removals from both Levallois and non-Levallois cores.

A number of sites from the Jurerru Valley have yielded Middle Paleolithic assemblages postdating the eruption of Toba. Luminescence age estimates for artefact assemblages from JWP3/3b, 20, 21, and 23 span 55-34 ka and indicate some continuity of technological behavior but with certain aspects of earlier practices subject to greater emphasis (Petraglia et al. 2012). Most notable is the more limited role of prepared-core (Levallois; discoidal) methods and greater focus on single platform cores (Clarkson, Jones, and Harris 2012). Meanwhile, continuity in the proportions of retouched tool types such as scrapers, notches and burins, and blades and microblades is observed (Clarkson, Jones, and Harris 2012). In contrast to this continuity in the presence of certain behaviors, it is within the context of these Late Middle Paleolithic assemblages that bipolar technologies first appear.

A Middle Paleolithic site with a clear component of blade production embedded in prepared-core technologies is Patne (James 2011). In spite of a stratigraphic disconformity between Middle and Late Paleolithic horizons at the site and the presence of only a single radiocarbon age estimate obtained in the 1980s, Patne remains a key feature of debate for Late Pleistocene behavioral change as a rare example of a single sedimentary sequence preserving evidence for the use of both industries.

\section{Late Paleolithic ( 45 ka Onward)}

Despite evidence for the Late Pleistocene antiquity of microlithic industries in Sri Lanka (i.e., Batadomba-Lena, Fa Hien, Kitugala Beli-Lena; Deraniyagala 1992) and in India (i.e., Patne; Sali 1985,1989), the early age of these technologies has only recently been widely accepted, as previous analysts considered these small-tool assemblages to be Holocene in age (Misra 1989). Realization of their antiquity is a consequence of increasing numbers of older chronometric ages from new excavations and detailed attribute-based lithic analyses that show developmental trends through time.

Excavations at Mehtakheri, in the Narmada Valley, currently present the oldest lithic assemblage argued to represent the shift to Late Paleolithic technologies and dating to $\sim 45 \mathrm{ka}$ (Mishra, Chauhan, and Singhvi 2013). Abraded (and undescribed) Middle Paleolithic artefacts are known from lower deposits dating to MIS 4. An assemblage of 849 artefacts is derived from Unit 2 at the site and is dated by a number of OSL age estimates and an 
infinite ${ }^{14} \mathrm{C}$ date, with the basal OSL date of $44.3 \pm 4.3 \mathrm{ka}$ (MHK09-10). Among these artefacts, two different reduction sequences are evident, one focusing on larger flake production from unidirectional or radial quartzite cores and the other centered on blade production from chalcedony and chert cores. The excavators identify the prominence of 10 microblade cores (mostly 20-30 mm), 50 complete blades, 100 broken blades, and two backed blades within the assemblage as key evidence to attribute the assemblage to the Late Paleolithic (Mishra, Chauhan, and Singhvi 2013). However, both the low density of diagnostic artefacts and limited published information regarding the dates, specifically the absence of dose rate distributions or report of aliquot sizes, complicate interpretations (see Groucutt et al. 2015b).

Recent surveys and excavations in West Bengal have identified the earliest Paleolithic sites in the eastern regions of South Asia within and eroding from pediment colluvium at the sites of Kana and Mahadeberra (Basak and Srivastava 2014). At Kana an assemblage attributed to the Late Paleolithic comprises seven blade cores (up to $60 \mathrm{~mm}$ in length) and $29 \mathrm{mi}$ croblade cores (between 20 and $40 \mathrm{~mm}$ in length) along with microblade debitage and large flakes from $40 \mathrm{~mm}$ and upward of $60 \mathrm{~mm}$ and is dated by OSL to $42 \pm 4 \mathrm{ka}$ (Kana- $1.4 \mathrm{~m}$ ). The larger buried Late Paleolithic assemblage at Mahadebbera $(n=111)$ dates between $25 \pm 3 \mathrm{ka}$ (Maha-0.69 $\mathrm{m}$ ) and $34 \pm$ $3 \mathrm{ka}$ (Maha-2.03 $\mathrm{m}$ ) and predominately focuses on microblade reduction and the production of retouched lunates, points, triangles, and backed blades.

An examination of the origins of Late Paleolithic technologies must, however, go beyond identification of the earliest microblade industries given the presence of blades and microblades in some late Middle Paleolithic assemblages. This is particularly pertinent in light of models for a gradual Middle to Late Paleolithic transition and questions over where to place the elongate-flake-focused assemblage from Riwat (Site 55) dating to $\sim 45 \mathrm{ka}$ (Dennell et al. 1992). Rather, there is a need to illuminate change across the breadth of technological behavior through time. Such detailed studies are available from Sri Lanka, the Jurreru Valley, and Patne.

In Sri Lanka, a number of new studies have been conducted within the past decade concerning the three key sites of Batadomba-Lena, Fa Hien, and Kitugala Beli-Lena. Roberts and colleagues (Roberts, Boivin, and Petraglia 2015) have undertaken a fresh assessment of the dating of these sites, conducting Bayesian modeling to help constrain the upper age ranges for occupation of the site. At Fa Hien, bulk sampling for radiocarbon dating in the oldest horizons results in an age bracket of 38.5-35 ka. Yielding human fossils as well as geometric microliths, beads, and bone tools, these horizons provide a critical benchmark for both the certain appearance of $H$. sapiens in the Indian subcontinent as well as a range of other "modern" behaviors. A conservative age estimate is presented by Roberts and colleagues (Roberts, Boivin, and Petraglia 2015) for the oldest horizons at Batadomba-Lena, a Bayesian modeling framework, offers a wide age bracket of 35-28 ka. At Ki- tugala Beli-Lena, an age bracket of $31-26 \mathrm{ka}$ is presented for the appearance of microlithic technologies (Roberts, Boivin, and Petraglia 2015). From the LGM onward, dating of these sites becomes significantly more refined, with long-term occupations at Batadomba-Lena and Kitugala Beli-Lena extending into the Holocene.

Lewis and colleagues (Lewis, Perera, and Petraglia 2014) have undertaken a technological assessment of a sample of lithic assemblages from the oldest Late Paleolithic horizons at Batadomba-Lena. Previous researchers have commented on the scarcity of retouched microlithic artefacts within these horizons, noting the large volumes of flakes and flaking debris. Lewis and colleagues (Lewis, Perera, and Petraglia 2014) have demonstrated that the inhabitants of the site were using flake blanks for retouching into typologically distinguishable microlithic forms. This marks a notable difference from contemporaneous sites in India where microblade reduction strategies provide blanks for retouched microlithic artefacts.

The excavations at Jwalapuram 9, a rock-shelter in the Jurreru Valley, have played a key role within the last decade for firmly establishing the Late Pleistocene antiquity of microlithic assemblages in mainland South Asia (Clarkson et al. 2009; Clarkson, Jones, and Harris 2012; Petraglia et al. 2009). The earliest Late Paleolithic horizon at Jwalapuram $9(>29.4 \pm 0.19 \mathrm{ka} \mathrm{BP}$ [shell aragonite, bivalve; OxA-14829]; >34.3-33.4 ka Cal BP) indicates the presence of a comparable proportion of notches and scrapers to the youngest Middle Paleolithic sites in the Jurreru Valley but a much larger proportion of microblades than previously present. A gradual decline in the proportion of scrapers and notches is evident in younger Late Paleolithic levels, in which microblade cores and backed artefacts become prominent features of lithic technology (Clarkson, Jones, and Harris 2012). Varying proportions of single and multiplatform cores, blades, burins, and bipolar flakes are also present, typically at lower proportion than in young Middle Paleolithic horizons (Clarkson, Jones, and Harris 2012). Alongside the rich record of lithic technology and long-term occupation history from $>34$ ka into the Holocene, the rich material culture at the site beyond lithic technology includes the production of nonlithic tools, stone beads, and human remains (Clarkson et al. 2009).

At Patne, a younger Late ("Upper") Paleolithic horizon (IIIA) was dated to $24.27 \pm 0.195 \mathrm{ka}$ BP (ostrich eggshell; GRN7200) through ${ }^{14} \mathrm{C}$ dating of an engraved fragment of ostrich eggshell underlying two further young Late Paleolithic levels and overlying five early Late Paleolithic and a single Middle Paleolithic horizon (Sali 1989). Sali $(1985,1989)$ identified a gradual decline in average size from $\sim 45 \mathrm{~mm}$ to $30 \mathrm{~mm}$ and a broad decrease in prevalence through time of burins, borers, scrapers, and retouched points. Prepared cores are present alongside blade cores only in the Middle Paleolithic and the two oldest Late Paleolithic horizons, whereas less formal flake cores are only present in the overlying four Late Paleolithic horizons. Retouched blades, including burinated and backed blades, first appear in the Late Paleolithic, whereas classic microlithic forms only appear in the younger Late Paleolithic 
horizons. Statistical analyses as part of an attribute-based study of a sample of these assemblages further corroborates these results (James 2011). Pairwise analyses between adjacent horizons within the stratigraphic sequence failed to identify significant differences in lithic technology, supporting gradual change between horizons. Only at a groupwise level were significant differences identified: between the Middle Paleolithic horizon and the youngest Late Paleolithic level.

In addition to these well-studied sites, the western area of the subcontinent offers further evidence for Late Paleolithic occupations. The earliest microlithic artefacts identified in the region date to $21 \pm 3 \mathrm{ka}$ (LD-1099) near Katoati (Blinkhorn 2012; Blinkhorn, Achyuthan, and Petraglia 2015). Assemblages at Buddha Pushkar, which appear to date to less than $27 \pm$ $2.6 \mathrm{ka}$ (PSH 92/3; Singhvi et al. 1994), offer further evidence for a gradual decrease in the size of blade and microblades through time (Allchin, Goudie, and Hegde 1978). Further evidence for the continued presence of a range of prepared-core technologies and retouched tool types known from regional Middle Paleolithic industries within Late Paleolithic assemblages is observed at Buddha Pushkar. The large number of Late Paleolithic assemblages dating to $>20 \mathrm{ka}$ (fig. 5) typically contain artefact inventories that considerably overlap with those reported above (James 2011). However, integrating them further into contemporary analyses is problematic because of frequent mixing of surface and buried artefacts, unsystematic sampling methods, and variable use of terminology over the extended time frame in which these sites have been originally recorded.

\section{Discussion}

\section{The Late Acheulean to Middle Paleolithic Transition}

Evidence from the Middle Son Valley dating between 140 and 125 ka suggests that Late Acheulean populations survived any climatic downturns toward the end of MIS 6 (fig. 3). Sites found elsewhere in central and western India may indicate that Late Acheulean populations were still present during MIS 5, up to $\sim 100 \mathrm{ka}$. However, such an assertion rests on minimum age ranges and requires further examination to support fully. The earliest currently known Middle Paleolithic horizon at Katoati, dating to $\sim 96 \mathrm{ka}$, follows this latter time frame closely, but by the end of MIS 5 (and close to the error range of the lowestdated level at Katoati), Middle Paleolithic occupations are known from numerous sites across South Asia. From this early appearance, Middle Paleolithic technologies combine preparedcore technologies (including varied Levallois schemes of reduction) with a diversified retouched flake tool kit, including unifacial and bifacial points and multiple forms of basal modifications (e.g., tangs, shoulders). This major change in South Asian technological behavior, from Late Acheulean to Middle Paleolithic technologies, appears to occur during MIS 5, significantly later than in other Old World regions (Adler et al. 2014; Kuhn 2013; Malinsky-Buller 2016; Porat et al. 2010; Tryon and McBrearty 2002; van Peer et al. 2003; White and Ashton 2004). Currently, the scarcity of archaeological assemblages with clear chronological control within MIS 5 makes any assessment of change during this phase difficult and an important target for future research.

In the absence of chronometric dating and often through the analysis of surface sites, many researchers have suggested substantial continuity from Late Acheulean to Middle Paleolithic industries. The apparent refinement of bifacial technologies throughout Late Acheulean assemblages and the continued appearance of diminutive bifaces within Middle Paleolithic assemblages, including at 16R Dune between 40 and $80 \mathrm{ka}$, has been suggested to illustrate transition between these two industries (e.g., Ajithprasad 2005). Continued use of bifacial technologies within Middle Paleolithic (and other) industries is, however, widespread in the Old World (e.g., Ruebens 2014; Tryon and Faith 2013). As a result, this continuity alone offers only limited insight into the nature of technological change, and a broader evaluation of how bifacial flaking approaches were used in different assemblages is clearly warranted. More recently, Mishra and colleagues (Mishra, Chauhan, and Singhvi 2013) assert continuity between Late Acheulean and Middle Paleolithic industries in South Asia on the absence of projectile or blade technologies in the latter. However, the presence of blade technologies among Middle Paleolithic industries is well established in South Asia (e.g., Misra 1982) and recently affirmed through dated studies (e.g., Blinkhorn 2014; Clarkson, Jones, and Harris 2012; Sali et al. 1989). Similarly, evaluation of Middle Paleolithic point technologies indicates that their use as projectiles cannot simply be ruled out (Costa 2012), especially considering the diverse forms of point technology within Middle Paleolithic sites (Blinkhorn, Achyuthan, and Ajithprasad 2015).

A more nuanced assessment of technological changes from Late Acheulean to Middle Paleolithic technologies has been undertaken by Shipton and colleagues (2013). In the Middle Son Valley, the dated Late Acheulean assemblage from Patpara and an undated Middle Paleolithic assemblage in the immediately overlying sediment unit were compared. In the final stages of Late Acheulean biface reduction, Shipton and colleagues (2013) identify their use as cores at the end of their use life with the raising of the plane of intersection between the two bifacial surfaces in order to strike invasive flakes from one surface. This hierarchical organization of flaking surfaces is argued to mark a clear step toward a critical concept underlying Levallois core technology, a major hallmark of the Middle Paleolithic. Within overlying Middle Paleolithic assemblages, greater levels of hierarchical organization of behavior and a recursive approach to blank production are widely apparent in the dominance of recurrent Levallois reduction strategies (Shipton et al. 2013). An alternate aspect of Levallois reduction is argued to be apparent in biface production in Late Acheulean levels at Bhimbetka, potentially dating to $\sim 100 \mathrm{ka}$ (Shipton 2016). Here, the ability to successfully strike large, end-struck flakes through the control of a shallow, symmetrical flaking surface for use as biface blanks is compared with the preparation and striking of Levallois flaking faces. Shipton (2016) postulates that this could indicate alternate routes for local innovation of key Middle 
Paleolithic technologies in different locations within South Asia. However, the examples from the Bhimbetka and the Middle Son Valley occur at the beginning and end of reduction sequences, respectively, and may form part of a wider technological approach. Critically, these studies illustrate that aspects of more complex, hierarchical, and recursive technological behavior were emerging in the youngest Late Acheulean industries within South Asia. As a result, a local transition from Late Acheulean to Middle Paleolithic clearly remains possible but demands more detailed evidence from MIS 5 to evaluate further.

\section{The Middle to Late Paleolithic Transition}

Debates surrounding the effect of the eruption of Toba $74 \mathrm{ka}$, the climatic effect of MIS 4 (as apparent in highly suppressed monsoonal intensity in fig. 3), and the dispersal of modern humans have led some researchers to question whether there is continuity between Middle Paleolithic industries from MIS 5 to MIS 3 (Ambrose 1998; Mellars et al. 2013). Research both in the Jurreru Valley and Thar Desert offer no indication of any stepwise change in technology within Middle Paleolithic industries but rather a gradual change in behavior. This is most apparent in the diversification of Middle Paleolithic core reduction practices from the onset of MIS 3, including the appearance of blade and bipolar technologies as targeted reduction strategies and a decrease in artefact size. It therefore appears that South Asian Middle Paleolithic technologies are not static but share the piecemeal appearance of new features that are also observed elsewhere.

The identification of significant change in lithic technology associated with the Late Pleistocene is focused most heavily on microlithic technology, reliance on blade production, and the use of backing as a retouch strategy. Although argued to mark a clear break from earlier technologies (Mishra, Chauhan, and Singhvi 2013), this is not borne out by evidence from Patne or the Jurreru Valley. These sites indicate bipolar techniques first appear embedded in Middle Paleolithic reduction strategies, decreasing blade sizes appear to transcend the Middle to Late Paleolithic transition, and backing only becomes apparent once blade reduction has become the dominant core technique. Further continuities from the Middle Paleolithic can be observed in the retouch tool kits associated with early Late Paleolithic assemblages and the continued use of alternate flake reduction strategies. This is apparent in isolated assemblages such as Mehtakheri and Kana as well as better-resolved sequences at Patne and the Jurreru Valley. Indeed, casting the appearance of Late Paleolithic technology as a revolutionary change has served to downplay the importance of variability within Late Paleolithic assemblages, which recent studies are starting to shed light on (e.g., Lewis 2015; Lewis, Perera, and Petraglia 2014).

Beyond lithic technology, however, a stark difference between Middle and Late Paleolithic is apparent in the diversity of material culture found in the latter phase. The appearance of nonlithic tools, such as antler and bone points; the production of beads and engravings on both stone and other materials, including ostrich eggshell; the use of ochre; and the presence of burials remain solely associated with Late Paleolithic assemblages. In the past, such forms of material culture were argued to be the result of uniquely modern human patterns of cognition (e.g., Klein 1995; Misra 2001). However, the appearance of such behavior among modern human populations occurred in a piecemeal fashion (e.g., James and Petraglia 2005; McBrearty and Brooks 2000), and there is now clear evidence that other human populations, such as Neanderthals, might have engaged in similar behavior (e.g., Finlayson et al. 2012). As a result, this change in material culture in South Asia may not simply relate to the arrival of a new population, and there are more complex factors potentially driving their emergence (e.g., Petraglia et al. 2009).

Currently, the earliest evidence for Late Paleolithic industries in South Asia occurs $\sim 45 \mathrm{ka}$, whereas the youngest securely dated Middle Paleolithic industries continue until $34 \mathrm{ka}$ (fig. 5). In addition to this significant temporal overlap between technologies, substantial spatial heterogeneity can be observed in the transition from Middle to Late Paleolithic industries across South Asia (fig. 6). No single epicenter from which Late Paleolithic technologies radiate can readily be identified. This complex pattern of behavior appears to occur in the context of strong but fluctuating monsoonal activity during mid-MIS 3 (fig. 3). By the end of MIS 3, Middle Paleolithic technologies appear to have mostly been replaced across South Asia.

\section{Explaining Cultural Developments in the Indian Subcontinent}

This review of contemporary evidence for technological change during the Late Pleistocene in South Asia indicates that (1) although a gradual evolution from Late Acheulean to Middle Paleolithic technologies is plausible, it is not currently well supported by the archaeological record, and (2) the transition from Middle to Late Paleolithic lithic industries is spatially and temporally varied and best characterized by gradual change with piecemeal additions of new technological approaches rather than a revolution in behavior. Unlike in the twentieth century, such apparent continuity cannot be resolved by suggesting longterm population continuity in the face of overwhelming evidence for the dispersal of modern humans. Meanwhile, no single behavior or checklist of behavioral traits appears both universal and unique among modern humans, making it difficult to securely identify the arrival of modern humans in South Asia. Explaining the patterns identified in the Late Pleistocene cultural record must accommodate both how gradual change in behavior may have occurred in the region and the dispersal of modern humans into South Asia.

Petraglia and colleagues (2009) argued that the combination of significant increases in population size in circumscribed regions, as apparent in the Jurreru Valley, and deteriorating climatic conditions during MIS 3 provided circumstances in which innovations led to the gradual replacement of Middle Paleolithic by Late Paleolithic technologies. Over the past decade there has been considerable interest in the influence of demography on innovation in Paleolithic societies. A number of recent studies 

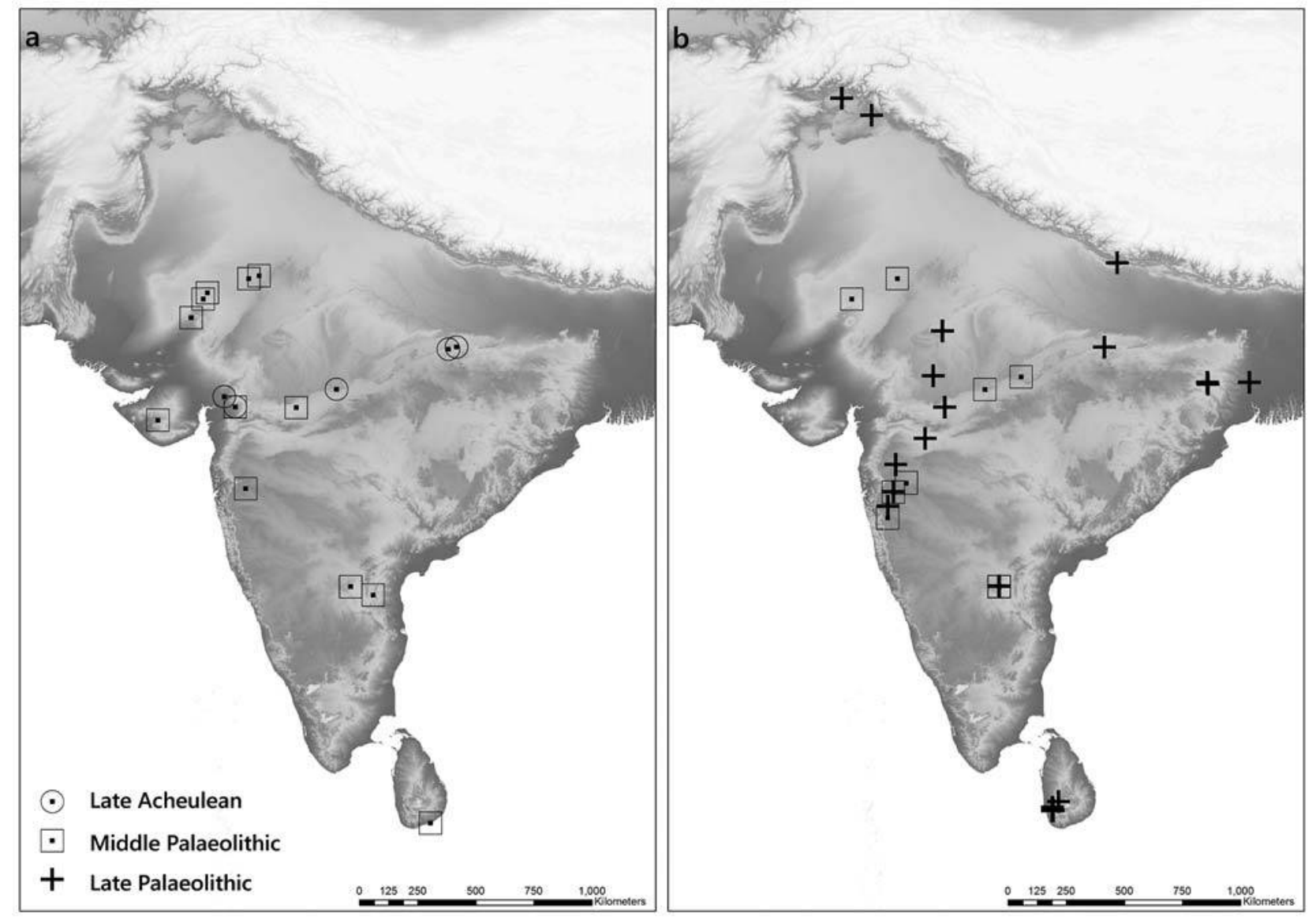

Figure 6. Map illustrating the changing quantity and distribution of dated Late Pleistocene sites in the Indian subcontinent from 50 to $140 \mathrm{ka}(a)$ and 30 to $50 \mathrm{ka}(b)$. A color version of this figure is available online.

now indicate that, rather than gross population size, it is population density and mobility strategies and their use to mitigate environmental/subsistence risk that may preserve and promote adaptive innovations (Collard, Buchanan, and O'Brien 2013; Grove 2015; Vaesen et al. 2016). The spatially, temporally, and technologically heterogeneous transition from Middle to Late Paleolithic technologies in South Asia could therefore result from discrete populations reaching critical thresholds of subsistence risk in different ecological settings.

Similar arguments have been made elsewhere, suggesting that the emergence of Middle Paleolithic technologies from Late Acheulean traditions resulted from the interplay between environmental and demographic factors (e.g., Adler et al. 2014). An increase in the amplitude and frequency of orbitally driven climate change from $\sim 500 \mathrm{ka}$ has been argued to have presented an important selective force for greater behavioral plasticity among Acheulean hominins (Potts 1998). This time frame also corresponds to a significant change in hominin life history clearly embodied in increased cranial capacities (Rightmire 2015) that may have enabled or been enabled by new forms of social relations (e.g., Foley and Gamble 2009). Regional differences in the expression of orbital climate change may explain the late persistence of Late Acheulean populations in South Asia. For instance, the tempo of changes related to monsoonal intensity, the particular mosaic of habitats the region sustains, or the nature of population structures they enable could have buffered subsistence stresses, offsetting the need for innovation. However, what changes may have occurred that led to a local innovation of Middle Paleolithic technology remains obscured.

Significant changes in the hominin demography of Asia are coincident with the transition from Late Acheulean to Middle Paleolithic technologies in the Indian subcontinent. Resolving between the fossil and genetic records of Asian hominins is complicated by a small number of fossils yielding Denisovan aDNA from North Asia and the diversity of South and East Asia fossil hominins that lack suitable aDNA preservation. This is particularly pertinent as mixed morphologies resulting from interbreeding have become a reality (Ackermann, Mackay, and Arnold 2015). Direct or indirect changes to the wider demography of Asia, such as through population or cultural diffusion, may have promoted conditions in which premodern human populations in South Asia locally developed Middle Paleolithic technologies.

Combined evidence from the fossil and archaeological record clearly illustrates that Homo sapiens were responsible for the production of Late Paleolithic industries in South Asia. For 
some researchers, this co-occurrence clearly indicates the earliest arrival of modern humans within South Asia supported by uniparental genetic studies of contemporary populations (Mellars et al. 2013; Mishra, Chauhan, and Singhvi 2013). Typological comparisons between material culture in southern Africa and South Asia have been suggested to indicate direct cultural inheritance between these regions as a proxy for human dispersals (Mellars 2006; Mellars et al. 2013). However, neither direct technological comparisons of lithic technologies (Lewis et al. 2015) nor wider interregional syntheses (Groucutt et al. $2015 a, 2015 b)$ support any form of cultural inheritance from MSA Howiesons Poort technologies in southern Africa or East African Later Stone Age industries with Late Paleolithic technologies in South Asia (contra Mellars 2006; Mellars et al. 2013). A variant of such models advanced by Mishra and colleagues (Mishra, Chauhan, and Singhvi 2013) suggests that earlier human expansions may have colonized other regions in Asia but that modern human populations were unable to outcompete South Asian archaic populations. While both populations used Middle Paleolithic technologies, it is argued that the resilience of South Asian archaics is due to existing adaptations to the region's ecology. Only armed with Late Paleolithic technologies were modern humans able to successfully supplant extant South Asian populations. This model is unable to explain apparent gradual changes in Middle Paleolithic industries in which key Late Paleolithic technological approaches first become manifest. Nor is this model consistent with the heterogeneous appearance of Late Paleolithic technologies within South Asia across time and space.

Population dispersals associated with Middle Paleolithic technologies were first mooted to explain the spread of Levallois technologies across the Old World (Lahr and Foley 1994). The dispersal of modern humans using Middle Paleolithic technologies is well attested to by the Levantine record with the presence of $H$. sapiens during MIS 5 evident at Skhul and Qafzeh (Mercier et al 1993; Grun et al. 2005). The expanding Middle Paleolithic record of Arabia during this time frame is also thought to document expansions of modern humans based on the appearance of technologies with direct antecedents in North and East Africa, such as at Jebel Faya (Armitage et al. 2011). Environmental approaches highlight the more northerly position of the ITCZ during interglacial conditions in MIS 5 resulting in significantly enhanced precipitation in the desert belt that may have enabled modern human dispersal at this time (Boivin et al. 2013; Groucutt and Blinkhorn 2013). Comparative studies have indicated significant similarities between South Asian Middle Paleolithic technologies and those attributed to $H$. sapiens in Africa and the Levant, leading to arguments for modern human dispersals into South Asia during MIS 5 (Clarkson, Jones, and Harris 2012; Petraglia et al. 2007). Critically, these analyses indicate no continuity between South Asian Late Paleolithic and those industries found to the west of the region.

While the appearance of modern humans in the Levant is coincident with the last securely dated Late Acheulean sites in South Asia, the appearance of Middle Paleolithic industries during MIS 5a now coincides with dated evidence for modern humans in East Asia, best known from Fuyan Cave (Liu et al. 2015). Similarly, the sole use of Middle Paleolithic technologies in South Asia overlaps with the appearance of modern humans in South East Asia (Mijares et al. 2010) and Australia (Clarkson et al. 2015; O'Connell and Allen 2015). The association between modern humans and Middle Paleolithic technologies cannot be verified without the enrichment of the South Asian fossil record. However, current fossil evidence from adjacent regions, environmental studies, and interregional technological comparisons point toward the early dispersal of modern humans into South Asia with Middle Paleolithic industries.

\section{Conclusion}

The results of interdisciplinary research in South Asia within the past decade have had a transformative effect on the archaeological record, enabling us to approach new questions regarding the timing and nature of major changes in hominin behavior and the dispersal of modern humans into the region. Increased chronological resolution has illuminated a spatially, temporally, and technologically heterogeneous transition from Middle to Late Paleolithic technologies. While the time frame for the Late Acheulean to Middle Paleolithic transition is not sufficiently resolved in the same level of detail, it now appears to occur at a time of demographic upheaval across South Asia. Converging lines of evidence both from South Asia and beyond point to the appearance of Middle Paleolithic technologies coinciding with the expansions of modern humans. In the absence of fossil discoveries that can decisively resolve current debate, formulating questions that can be resolved by investigating South Asia's rich Paleolithic heritage is important. Combining investigations into technological diversification, ecological adaptation, and population structure in South Asia opens up the possibility of understanding what factors promote creativity and innovation among Late Pleistocene populations and comparing how this is expressed at an interregional level.

\section{Acknowledgments}

Our thanks go to all participants of the "Human Colonization of Asia in the Late Pleistocene" symposium for an illuminating and highly enjoyable meeting in Sintra and particularly Leslie Aiello, Laurie Obbink, and the co-organizers Christopher Bae and Katerina Douka. We are especially grateful to our South Asian collaborators as well as the international researchers with whom we have worked on projects within the Indian subcontinent and for the countless discussions with our colleagues that provide the background to the synthesis we have presented. Our manuscript was improved following comments from two anonymous reviewers. 


\section{References Cited}

Ackermann, R. R., A. Mackay, and M. L. Arnold. 2015. The hybrid origin of "modern" humans. Evolutionary Biology 43:1-11.

Adler, D. S., K. N. Wilkinson, S. Blockley, D. F. Mark, R. Pinhasi, B. A. Schmidt-Magee, S. Nahapetyan, et al. 2014. Early Levallois technology and the Lower to Middle Paleolithic Transition in the southern Caucasus. Science 345:1609-1613.

Agrawal, D. P., and A Ghosh. 1973. Radiocarbon and Indian archaeology. Bombay: Tata Institute.

Ajithprasad, P. 2005. Early Middle Paleolithic: a transition phase between the Upper Acheulian and Middle Paleolithic cultures in the Orsang Valley, Gujarat. Man and Environment 30:1-11.

Allchin, B., A. Goudie, and K. Hegde. 1978. Prehistory and paleogeography of the Great Indian Desert. London: Academic Press.

Ambrose, S. H. 1998. Late Pleistocene human population bottlenecks, volcanic winter, and differentiation of modern humans. Iournal of Human Evolution 34:623-651.

Armitage, S. J., S. A. Jasim, A. E. Marks, A. G. Parker, V. I. Usik, and H.-P. Uerpmann. 2011. The southern route "out of Africa": evidence for an early expansion of modern humans into Arabia. Science 331:453-456.

Athreya, S. 2015. Modern human emergence in South Asia: a review of the fossil and genetic evidence. In Emergence and diversity of modern human behavior in Paleolithic Asia. Yousuke Kaifu, Masami Izuho, Ted Goebel, Hiroyuki Sato, and Akira Ono, eds. Pp. 61-79. College Station: Texas A\&M University Press

Barker, G., H. Barton, M. Bird, P. Daly, I. Datan, A. Dykes, L. Farr, et al. 2007. The "human revolution" in lowland tropical Southeast Asia: the antiquity and behavior of anatomically modern humans at Niah Cave (Sarawak, Borneo). Journal of Human Evolution 52:243-261.

Basak, B., and P. Srivastava. 2014. Earliest dates and implications of microlithic industries of Late Pleistocene from Mahadebbera and Kana, Purulia District, West Bengal. Current Science 107:1167-1171.

Bednarik, R. G., G. Kumar, A. Watchman, and R. G. Roberts. 2005. Preliminary results of the EIP Project. Rock Art Research 22:147-197.

Blinkhorn, J. 2012. The Paleolithic occupation of the Thar Desert. DPhil thesis, University of Oxford.

. 2013. A new synthesis of evidence for the Upper Pleistocene occupation of 16R Dune and its southern Asian context. Quaternary International 300:282-291.

2014. Late Middle Paleolithic surface sites occurring on dated sediment formations in the Thar Desert. Quaternary International 350:94-104.

Blinkhorn, J., H. Achyuthan, and P. Ajithprasad. 2015. Middle Paleolithic point technologies in the Thar Desert, India. Quaternary International 382:237-249.

Blinkhorn, J., H. Achyuthan, P. Ditchfield, and M. Petraglia. 2017. Paleoenvironmental dynamics and Paleolithic occupation at Katoati, Thar Desert, India. Quaternary Research 87:298-313.

Blinkhorn, J., H. Achyuthan, and M. D. Petraglia. 2015. Ostrich expansion into India during the Late Pleistocene: implications for continental dispersal corridors. Palaeogeography, Palaeoclimatology, Palaeoecology 417:80-90.

Blinkhorn, J., H. Achyuthan, M. Petraglia, and P. Ditchfield. 2013. Middle Paleolithic occupation in the Thar Desert during the Upper Pleistocene: the signature of a modern human exit out of Africa? Quaternary Science Reviews 77:233-238

Blinkhorn, J., A. G. Parker, P. Ditchfield, M. Haslam, and M. Petraglia. 2012. Uncovering a landscape buried by the super-eruption of Toba, 74,000 years ago: a multi-proxy environmental reconstruction of landscape heteroge neity in the Jurreru Valley, South India. Quaternary International 258:135147.

Boivin, N., D. Q. Fuller, R. Dennell, R. Allaby, and M. D. Petraglia. 2013. Human dispersal across diverse environments of Asia during the Upper Pleistocene. Quaternary International 300:32-47.

Bolton, C. T., L. Chang, S. C. Clemens, K. Kodama, M. Ikehara, M. MedinaElizalde, G. A. Paterson, et al. 2013. A 500,000 year record of Indian summer monsoon dynamics recorded by Eastern Equatorial Indian Ocean upper water column structure. Quaternary Science Reviews 77:167-180.

Braconnot, P., B. Otto-Bliesner, S. Harrison, S. Joussaume, J.-Y. Peterchmitt, A. Abe-Ouchi, M. Crucifix, et al. 2007. Results of PMIP2 coupled simulations of the Mid-Holocene and Last Glacial Maximum. 1. Experiments and large-scale features. Climate of the Past 3:261-277.

Caley, T., B. Malaizé, S. Zaragosi, L. Rossignol, J. Bourget, F. Eynaud, P. Martinez, J. Giraudeau, K. Charlier, and N. Ellouz-Zimmermann. 2011.
New Arabian Sea records help decipher orbital timing of Indo-Asian monsoon. Earth and Planetary Science Letters 308:433-444.

Caley, T., S. Zaragosi, J. Bourget, P. Martinez, B. Malaizé, F. Eynaud, L. Rossignol, T. Garlan, and N. Ellouz-Zimmermann. 2013. Southern Hemisphere imprint for Indo-Asian summer monsoons during the Last Glacial Period as revealed by Arabian Sea productivity records. Biogeosciences 10:7347-7359.

Cameron, D., R. Patnaik, and A. Sahni. 2004. The phylogenetic significance of the Middle Pleistocene Narmada Hominin cranium from Central India. International Journal of Osteoarchaeology 14:419-447.

Cann, R. L., M. Stoneking, and A. C. Wilson. 1987. Mitochondrial DNA and human evolution. Nature 325:31-36.

Chamyal, L. S., D. M. Maurya, R. Raj, N. Juyal, S. Bhandari, R. K. Pant, and C. Gaillard. 2011. Discovery of a robust fossil Homo sapiens in India (Orsang River Valley, Lower Narmada Basin, Gujarat): possible continuity with Asian Homo erectus. Acta Anthropologica Sinica 2:158-191.

Chauhan, P. R., S. Ozarkar, and S. Kulkarni. 2015. Genes, stone tools, and modern human dispersals in the center of the Old World. In Emergence and diversity of modern human behavior in Paleolithic Asia. Y. Kaifu, Masami Izuho, Ted Goebel, H. Sato, and Akira Ono, eds. Pp. 94-113. College Station: Texas A\&M University Press.

Clarkson, C., S. Jones, and C. Harris. 2012. Continuity and change in the lithic industries of the Jurreru Valley, India, before and after the Toba eruption. Quaternary International 258:165-179.

Clarkson, C., M. Petraglia, R. Korisettar, M. Haslam, N. Boivin, A. Crowther, P. Ditchfield, et al. 2009. The oldest and longest enduring microlithic sequence in India: 35000 years of modern human occupation and change at the Jwalapuram Locality 9 rockshelter. Antiquity 83:326-348.

Clarkson, C., M. Smith, B. Marwick, R. Fullagar, L. A. Wallis, P. Faulkner, T. Manne, et al. 2015. The archaeology, chronology and stratigraphy of Madjedbebe (Malakunanja II): a site in Northern Australia with early occupation. Journal of Human Evolution 83:46-64.

Clemens, S. C., and W. L. Prell. 2003. A 350,000 year summer monsoon multi-proxy stack from the Owen Ridge, Northern Arabian Sea. Marine Geology 201:35-51.

Clemens, S. C., W. L. Prell, D. W. Murray, G. B. Shimmield, and G. Weedon. 1991. Forcing mechanisms of the Indian Ocean monsoon. Nature 353:720725

Collard, M., B. Buchanan, and M. J. O'Brien. 2013. Population size as an explanation for patterns in the Paleolithic archaeological record: more caution is needed. Current Anthropology 54(suppl. 8):S388-S396.

Connell, J. F. O., and J. Allen. 2015. The process, biotic impact, and global implications of the human colonization of Sahul about 47,000 years ago. Journal of Archaeological Science 56:73-84.

Costa, A. G. 2012. Were there stone-tipped armatures in the South Asian Middle Paleolithic? Quaternary International 269:22-30.

Demeter, F., L. L. Shackelford, A.-M. Bacon, P. Duringer, K. Westaway, T. Sayavongkhamdy, J. Braga, et al. 2012. Anatomically modern human in Southeast Asia (Laos) by $46 \mathrm{Ka}$. Proceedings of the National Academy of Sciences of the USA 109:14375-14380.

Dennell, R. W., H. M. Rendell, M. Halim, and E. Moth. 1992. A 45,000-year-old open-air Paleolithic site at Riwat, northern Pakistan. Iournal of Field Archaeology 19:17-33.

Deraniyagala, S. U. 1992. The prehistory of Sri Lanka: an ecological perspective. Colombo: Department of Archaeological Survey, Government of Sri Lanka.

Finlayson, C. 2013. The water optimisation hypothesis and the human occupation of the mid-latitude belt in the Pleistocene. Quaternary International 300:22-31.

Finlayson, C., K. Brown, R. Blasco, J. Rosell, J. J. Negro, G. R. Bortolotti, G. Finlayson, et al. 2012. Birds of a feather: Neanderthal exploitation of raptors and corvids. PLOS ONE 7:e45927.

Foley, R., and C. Gamble. 2009. The ecology of social transitions in human evolution. Philosophical Transactions of the Royal Society B 364:3267-3279.

Gadgil, S. 2003. The Indian monsoon and its variability. Annual Review of Earth and Planetary Sciences 31:429-467.

Gaillard, C. 1993. Contribution à la connaissance du paléolithique inférieurmoyen en Inde. $\mathrm{PhD}$ thesis, Université de Provence.

Green, R. E., J. Krause, A. W. Briggs, T. Maricic, U. Stenzel, M. Kircher, N. Patterson, et al. 2010. A draft sequence of the Neandertal genome. Science 328:710-722.

Groucutt, H. S., and J. Blinkhorn. 2013. The Middle Paleolithic in the desert and its implications for understanding hominin adaptation and dispersal. Quaternary International 300:1-12. 
Groucutt, H. S., M. D. Petraglia, G. Bailey, E. M. L. Scerri, A. Parton, L. ClarkBalzan, R. P. Jennings, et al. 2015a. Rethinking the dispersal of Homo sa piens out of Africa. Evolutionary Anthropology: Issues, News, and Reviews 24:149-164.

Groucutt, H. S., E. M. L. Scerri, L. Lewis, L. Clark-Balzan, J. Blinkhorn, R. P. Jennings, A. Parton, and M. D. Petraglia. 2015b. Stone tool assemblages and models for the dispersal of Homo sapiens out of Africa. Quaternary International 382:8-30.

Grove, M. 2015. Paleoclimates, plasticity, and the early dispersal of Homo sapiens. Quaternary International 369:17-37.

Grun, R., C. Stringer, F. McDermott, R. Nathan, N. Porat, S. Robertson, L. Taylor, G. Mortimer, S. Eggins, and M. McCulloch. 2005. U-Series and ESR analyses of bones and teeth relating to the human burials from Skhul. Lournal of Human Evolution 49:316-334.

Guo, Z., S. Peng, Q. Hao, and P. E. Biscaye. 2004. Late Miocene-Pliocene development of Asian aridification as recorded in the red-earth formation in northern China. Global and Planetary Change 41:135-145.

Guo, Z. T., William F. Ruddiman, Q. Z. Hao, H. B. Wu, and Y. S. Qiao. 2002. Onset of Asian desertification by 22 myr ago inferred from loess deposits in China. Nature 416:159-163.

Harpending, H. C., S. T. Sherry, A. R. Rogers, M. Stoneking, and A. Lane. 1993. The genetic structure of ancient human populations. Current Anthropology 34:483-496.

Haslam, M., C. Clarkson, R. G. Roberts, J. Bora, R. Korisettar, P. Ditchfield, A. R. Chivas, et al. 2012. A southern Indian Middle Paleolithic occupation surface sealed by the $74 \mathrm{Ka}$ Toba eruption: further evidence from Jwalapuram Locality 22. Quaternary International 258:148-164.

Haslam, M., R. G. Roberts, C. Shipton, J. N. Pal, J. L. Fenwick, P. Ditchfield, N. Boivin, A. K. Dubey, M. C. Gupta, and M. Petraglia. 2011. Late Acheulean hominins at the marine isotope stage 6/5e transition in north-central India. Quaternary Research 75:670-682.

Hinsbergen, D. J. J. Van, P. C. Lippert, G. Dupont-Nivet, and N. McQuarrie. 2012. Greater India basin hypothesis and a two-stage Cenozoic collision between India and Asia. Proceedings of the National Academy of Sciences of the USA 109:7659-7664.

Imbrie, J., J. D. Hays, D. G. Martinson, A. McIntyre, A. C. Mix, J. J. Morley, N. G. Pisias, W. L. Prell, and N. J. Shackleton. 1984. The orbital theory of Pleistocene climate: support from a revised chronology of the marine $\mathrm{d} 18 \mathrm{O}$ record. In Milankovitch and climate: understanding the response to astronomical forcing: proceedings of the NATO Advanced Research Workshop held 30 November-4 December, 1982 in Palisades, NY. A. Berger, J. Imbrie, H. Hays, G. Kukla, and B. Saltzman, eds. Pp. 269-305. Dordrecht: Reidel.

James, H. V. A. 2011. Becoming human: the emergence of modern human behaviour in South Asia. $\mathrm{PhD}$ thesis, University of Cambridge.

James, H. V. A., and M. D. Petraglia. 2005. Modern human origins and the evolution of behavior in the Later Pleistocene record of South Asia. Current Anthropology 46(suppl. 5):S3-S27.

Juyal, N., R. Raj, D. M. Maurya, L. S. Chamyal, and A. K. Singhvi. 2000. Chronology of Late Pleistocene environmental changes in the lower Mahi basin, western India. Lournal of Quaternary Science 15:501-508.

Kathayat, G., H. Cheng, A. Sinha, C. Spötl, R. L. Edwards, H. Zhang, X. Li, et al. 2016. Indian monsoon variability on millennial-orbital timescales. Scientific Reports 6:4-10.

Kennedy, K. A. R. 2000. God-apes and fossil men: anthropology of South Asia. Ann Arbor: University of Michigan Press.

Kennedy, K. A. R., and S. U. Deraniyagala. 1989. Fossil remains of 28,000 year-old hominids from Sri Lanka. Current Anthropology 30:394-399.

Klein, R. G. 1995. Anatomy, behavior, and modern human origins. Iournal of World Prehistory 9:167-198.

Koch, P. L., and A. D. Barnosky. 2006. Late Quaternary extinctions: state of the debate. Annual Review of Ecology, Evolution, and Systematics 37:215-250.

Korisettar, R. 2007. Toward developing a basin model for Paleolithic settlement of the Indian subcontinent: geodynamics, monsoon dynamics, habitat diversity and dispersal routes. In The evolution and history of human populations in South Asia. M. D. Petraglia and B. Allchin, eds. Pp. 69-96. Dordrecht: Springer.

Kuhlwilm, M., I. Gronau, M. J. Hubisz, C. De Filippo, J. Prado-Martinez, M. Kircher, Q. Fu, et al. 2016. Ancient gene flow from early modern human into eastern Neanderthals. Nature 530:429-433.

Kuhn, S. L. 2013. Roots of the Middle Paleolithic in Eurasia. Current Anthropology 54(suppl. 8):S255-S268.

Lahr, M. M., and Robert Foley. 1994. Multiple dispersals and modern human origins. Evolutionary Anthropology: Issues, News, and Reviews 3:48-60.
Leuschner, D. C., and F. Sirocko. 2003. Orbital insolation forcing of the Indian monsoon: a motor for global climate changes? Palaeogeography, Palaeoclimatology, Palaeoecology 197:83-95.

Lewis, L. 2015. Early microlithic technologies and behavioural variability in Southern Africa and South Asia. DPhil thesis, University of Oxford.

Lewis, L., N. Perera, and M. Petraglia. 2014. First technological comparison of Southern African Howiesons Poort and South Asian microlithic industries: an exploration of inter-regional variability in microlithic assemblages. Quaternary International 350:7-25.

Li, J., X. Fang, C. Song, B. Pan, Y. Ma, and M. Yan. 2014. Late MioceneQuaternary rapid stepwise uplift of the NE Tibetan Plateau and its effects on climatic and environmental changes. Quaternary Research 81:400-423.

Liu, W., M. Martinon-Torres, Y.-J. Cai, S. Xing, H.-W. Tong, S.-W. Pei, M. J. Sier, et al. 2015. The earliest unequivocally modern humans in southern China. Nature 526:696-699.

Liu, Z. 2011. Atmospheric science: glacial cycles and Indian monsoonsouthern push. Science 333:706-708.

Malinsky-Buller, A. 2016. The muddle in the Middle Pleistocene: the Lower-Middle Paleolithic transition from the Levantine. Journal of World Prehistory 29:1-78.

Mani, M. S., ed. 2012. Ecology and biogeography in India. Dordrecht: Springer Science and Business Media.

McBrearty, S., and A. S. Brooks. 2000. The revolution that wasn't: a new interpretation of the origin of modern human behaviour. Lournal of Human Evolution 39:453-563.

Mellars, P. 2006. Going east: new genetic and archaeological perspectives on the modern human colonization of Eurasia. Science 313:796-800.

Mellars, P., K. C. Gori, M. Carr, P. A. Soares, and M. B. Richards. 2013. Genetic and archaeological perspectives on the initial modern human colonization of southern Asia. Proceedings of the National Academy of Sciences of the USA 110:10699-10704.

Mercier, N., H. Valladas, O. Bar-Yosef, B. Vandermeersch, C. Stringer, and J.-L. Joron. 1993. Thermoluminescence date for the Mousterian burial site of Es-Skhul, Mt. Carmel. Journal of Archaeological Science 20:169-174.

Mijares, A. S., F. Détroit, P. Piper, R. Grün, P. Bellwood, M. Aubert, G. Champion, N. Cuevas, A. De Leon, and E. Dizon. 2010. New evidence for a 67,000-year-old human presence at Callao Cave, Luzon, Phillipines. Iournal of Human Evolution 59:123-132.

Mishra, S., N. Chauhan, and A. K. Singhvi. 2013. Continuity of microblade technology in the Indian subcontinent since $45 \mathrm{Ka}$ : implications for the dispersal of modern humans. PLOS ONE 8:e69280.

Misra, V. N. 1982. Evolution of the blade element in the stone industries of the rock shelter III F23, Bhimbetka. In Indian archaeology: new perspectives. K. Sharma, ed. Pp. 7-13. Delhi: Agam Kala Prakashan.

. 1989. Stone Age India: an ecological perspective. Man and Environment 14:17-64.

. 2001. Prehistoric human colonization of India. Journal of Biosciences 26:491-531.

Misra, V. N, and S. N. Rajaguru. 1989. Paleoenvironments and prehistory of the Thar Desert, Rajasthan, India. In South Asian archaeology 1985. K. Frifelt and P. Sørensen, eds. Pp. 296-320. Occasional Papers, Scandinavian Institute of Asian Studies, Kopenhagen, 8. London: Curzon.

Molnar, P., P. England, and J. Martinod. 1993. Mantle dynamics, uplift of the Tibetan Plateau, and the Indian monsoon. Reviews of Geophysics 31:357-396.

Nielsen, R., J. M. Akey, M. Jakobsson, J. K. Pritchard, S. Tishkoff, and E. Willerslev. 2017. Tracing the peopling of the world through genomics. Nature 541:302-310.

Olson, D. M., E. Dinerstein, E. D. Wikramanayake, N. D. Burgess, G. V. Powell, E. C. Underwood, J. A. D’amico, et al. 2001. Terrestrial ecoregions of the world: a new map of life on Earth; a new global map of terrestrial ecoregions provides an innovative tool for conserving biodiversity. BioScience 51:933-938.

Oppenheimer, S. 2012. A single southern exit of modern humans from Africa: before or after Toba? Quaternary International 258:88-99.

Otto-Bliesner, B. L., S. J. Marshall, J. T. Overpeck, G. H. Miller, and A. Hu. 2006. Simulating Arctic climate warmth and icefield retreat in the last interglaciation. Science 311:1751-1753.

Pal, J. N. 2002. The Middle Paleolithic culture of South Asia. In Indian archeology in retrospect: archaeology and interactive disciplines. S. Settar and R. Korisettar, eds. Pp. 67-83. Manohar: Indian Council of Historical Research.

Pal, J. N., M. A. J. Williams, M. Jaiswal, and A. K. Singhvi. 2005. Infra-red stimulated luminescence ages for prehistoric cultures in the Son and Belan Valleys, north central India. Journal of Interdisciplinary Studies in History and Archaeology 1:51-62. 
Patnaik, R., P. R. Chauhan, M. R. Rao, B. A. B. Blackwell, A. R. Skinner, Ashok Sahni, M. S. Chauhan, and H. S. Khan. 2009. New geochronological, climatological, and archaeological data from the Narmada Valley hominin locality, Central India. Journal of Human Evolution 56:114-133.

Peer, P. Van, R. Fullagar, S. Stokes, R. M. Bailey, and J. Moeyersons. 2003. The Early to Middle Stone Age transition and the emergence of modern human behaviour at Site 8-B-11, Sai Island, Sudan. Iournal of Human Evolution 45:187-193.

Perera, N., N. Kourampas, I. Simpson, S. U. Deraniyagala, D. Bulbeck, J. Kamminga, J. Perera, D. Q. Fuller, K. Szabó, and N. V. Oliveira. 2011. People of the ancient rainforest: Late Pleistocene foragers at the Batadomba-lena rockshelter, Sri Lanka. Journal of Human Evolution 61:254-269.

Petit, J. R., J. Jouzel, D. Raynaud, N. I. Barkov, J. M. Barnola, I. Basile, M. Bender, et al. 1999. Climate and atmospheric history of the past 420,000 years from the Vostok ice core, Antarctica. Nature 399:429-436.

Petraglia, M., C. Clarkson, N. Boivin, M. Haslam, R. Korisettar, G. Chaubey, P. Ditchfield, et al. 2009. Population increase and environmental deterioration correspond with microlithic innovations in South Asia ca. 35,000 years ago. Proceedings of the National Academy of Sciences of the USA 106:12261-12266.

Petraglia, M. D., P. Ditchfield, S. Jones, R. Korisettar, and J. N. Pal. 2012. The Toba volcanic super-eruption, environmental change, and hominin occupation history in India over the last 140,000 years. Quaternary International 258:119-134.

Petraglia, M. D., M. Haslam, D. Q. Fuller, N. Boivin, and C. Clarkson. 2010 Out of Africa: new hypotheses and evidence for the dispersal of Homo sapiens along the Indian Ocean rim. Annals of Human Biology 37:288-311.

Petraglia, M., R. Korisettar, N. Boivin, C. Clarkson, P. Ditchfield, S. Jones, J. Koshy, et al. 2007. Middle Paleolithic assemblages from the Indian subcontinent before and after the Toba super-eruption. Science 317:114116.

Porat, N., M. Chazan, R. Grün, M. Aubert, V. Eisenmann, and L. Kolska Horwitz. 2010. New radiometric ages for the Fauresmith industry from Kathu Pan, Southern Africa: implications for the Earlier to Middle Stone Age transition. Journal of Archaeological Science 37:269-283.

Potts, R. 1998. Variability selection in hominid evolution. Evolutionary Anthropology 7:81-96.

Prüfer, K., F. Racimo, N. Patterson, F. Jay, S. Sankararaman, S. Sawyer, A. Heinze, et al. 2014. The complete genome sequence of a Neanderthal from the Altai Mountains. Nature 505:43-49.

Raghavan, H., S. N. Rajaguru, and V. N. Misra. 1989. Radiometric dating of a Quaternary dune section, Didwana, Rajasthan. Man and Environment 13:19-22.

Raju, D. R., and P. C. Venkatasubbaiah. 2002. The archaeology of the Upper Paleolithic phase in India. In Indian archeology in retrospect: archaeology and interactive disciplines. S. Settar and R. Korisettar, eds. Pp. 85-109. Manohar: Indian Council of Historical Research.

Rasmussen, M., X. Guo, Y. Wang, K. E. Lohmueller, S. Rasmussen, A. Albrechtsen, L. Skotte, et al. 2011. An Aboriginal Australian genome reveal separate human dispersals into Asia. Science 334:94-98.

Reich, D., R. E. Green, M. Kircher, J. Krause, N. Patterson, E. Y. Durand, B. Viola, et al. 2010. Genetic history of an archaic hominin group from Denisova Cave in Siberia. Nature 468:1053-1060.

Reyes-Centeno, H., S. Ghirotto, F. Détroit, D. Grimaud-Hervé, and G. Barbujani 2014. Genomic and cranial phenotype data support multiple modern human dispersals from Africa and a southern route into Asia. Proceedings of the $\mathrm{Na}$ tional Academy of Sciences of the USA 111:7248-7253.

Rightmire, G. P. 2015. Later Middle Pleistocene Homo. In Handbook of pa leoanthropology. W. Henke and Ian Tattersall, eds. Pp. 2221-2242. Berlin Springer.

Roberts, P., N. Boivin, and M. Petraglia. 2015. The Sri Lankan "microlithic" tradition c. 38,000 to 3,000 years ago: tropical technologies and adaptations of Homo sapiens at the southern edge of Asia. Journal of World Prehistory 28:69-112.

Roberts, P., E. Delson, P. Miracle, P. Ditchfield, R. G. Roberts, Z. Jacobs, J. Blinkhorn, et al. 2014. Continuity of mammalian fauna over the last $200,000 \mathrm{Y}$ in the Indian subcontinent. Proceedings of the National Academ of Sciences of the USA 111:5848-5853.

Ruebens, K. 2014. Late Middle Paleolithic bifacial technologies across Northwest Europe: typo-technological variability and trends. Quaternar International 350:130-146.

Sali, S. A. 1985. The Upper Paleolithic culture at Patne, District Jalgaon, Maharashtra. In Recent advances in Indo-Pacific prehistory. V. N. Misra and Peter Bellwood, eds. Pp. 137-145. New Delhi: Indo-Pacific Prehistory Association.
1989. The Upper Paleolithic and Mesolithic cultures of Maharashtra. Pune: Deccan College, Post-Graduate and Research Institute.

Sankararaman, S., S. Mallick, N. Patterson, S. Sankararaman, S. Mallick, N. Patterson, and D. Reich. 2016. The combined landscape of Denisovan and Neanderthal ancestry in present-day humans report. Current Biology 26:1-7.

Sankhyan, A. R. 2013. The emergence of Homo sapiens in South Asia: the Central Narmada Valley as witness. Human Biology Review 2:136-152.

Shipton, C. 2016. Hierarchical organization in the Acheulean to Middle Paleolithic Transition at Bhimbetka, India. Cambridge Archaeological Journal 26:601-618.

Shipton, C., C. Clarkson, J. N. Pal, S. C. Jones, R. G. Roberts, C. Harris, M. C. Gupta, P. W. Ditchfield, and M. D. Petraglia. 2013. Generativity, hierarchical action and recursion in the technology of the Acheulean to Middle Paleolithic transition: a perspective from Patpara, the Son Valley, India. Journal of Human Evolution 65:93-108.

Singhvi, A. K., D. Banerjee, S. N. Rajaguru, and V. S. Kishan Kumar. 1994. Luminescence chronology of a fossil dune at Budha Pushkar, Thar Desert: palaeoenvironmental and archaeological implications. Current Science 66:770-773.

Singhvi, A. K., S. U. Deraniyagala, and D. Sengupta. 1986. Thermoluminescence dating of Quaternary red-sand beds: a case study of coastal dunes in Sri Lanka. Earth and Planetary Science Letters 80:139-144.

Singhvi, A. K., M. A. J. Williams, S. N. Rajaguru, V. N. Misra, S. Chawla, S. Stokes, N. Chauhan, T. Francis, R. K. Ganjoo, and G. S. Humphreys. 2010. A $\sim 200$ ka record of climatic change and dune activity in the Thar Desert, India. Quaternary Science Reviews 29:3095-3105.

Sonakia, A., and K. A. R. Kennedy. 1985. Skull cap of an early man from the Narmada Valley alluvium (Pleistocene) of Central India. American Anthropologist 87:612-616.

Stoneking, M. 1989. DNA and recent human evolution. Evolutionary Anthropology 2:60-73.

Stringer, C. 2000. Paleoanthropology: coasting out of Africa. Nature 405:24-27.

Tryon, C. A., and J. T. Faith. 2013. Variability in the Middle Stone Age of Eastern Africa. Current Anthropology 54:S234-S254.

Tryon, C. A., and S. McBrearty. 2002. Tephrostratigraphy and the Acheulian to Middle Stone Age transition in the Kapthurin Formation, Kenya. Journal of Human Evolution 42:211-235.

United Nations Department of Economic and Social Affairs and Population Division. 2015. World population prospects: the 2015 revision, key findings and advance tables. Working Paper, No. ESA/P/WP. 241. New York: United Nations.

US Geological Survey. 2006. Shuttle radar topography mission. College Park: Global Land Cover Facility, University of Maryland.

Vaesen, K., M. Collard, R. Cosgrove, and W. Roebroeks. 2016. Population size does not explain past changes in cultural complexity. Proceedings of the National Academy of Sciences of the USA 113:2241-2247.

Wang, P. 1999. Response of Western Pacific marginal seas to glacial cycles: oceanographic and sedimentological features. Marine Geology 156:5-39.

Wang, P., S. Clemens, L. Beaufort, P. Braconnot, G. Ganssen, Z. Jian, P. Kershaw, and M. Sarnthein. 2005. Evolution and variability of the Asian monsoon system: state of the art and outstanding issues. Quaternary Science Reviews 24:595-629.

White, M. J., and N. Ashton. 2004. Lower Paleolithic core technology and the origins of the Levallois method in North-Western Europe. Current Anthropology 44:598-609.

Williams, M. A. J., and M. F. Clarke. 1995. Quaternary geology and prehistoric environments in the Son and Belan Valleys, north central India. In Quaternary environments and geoarchaeology of India. S. Wadia, R. Korisettar, and V. S. Kale, eds. Pp. 282-308. Bangalore: Geological Society of India.

Williams, M. A. J., J. N. Pal, M. Jaiswal, and A. K. Singhvi. 2006. River response to Quaternary climatic fluctuations: evidence from the Son and Belan Valleys, north-central India. Quaternary Science Reviews 25:2619-2631.

Yi, Liang, H.-J. Yu, J. D. Ortiz, X.-Y. Xu, S.-L. Chen, and J.-L. Ge. 2012. Quaternary linkage of sedimentary records to three astronomical rhythms and the Asian monsoon, inferred from a coastal borehole in the South Bohai Sea, China. Palaeogeography, Palaeoclimatology, Palaeoecology 329/330:101-117.

Zhisheng, A., S. C. Clemens, J. Shen, X. Qiang, Z. Jin, Y. Sun, W. L. Prell, et al. 2011. Glacial-interglacial Indian summer monsoon dynamics. Science 333: 719-723.

Zhisheng, A., J. E. Kutzbach, W. L. Prell, and S. C. Porter. 2001. Evolution of Asian monsoons and phased uplift of the Himalaya-Tibetan Plateau since Late Miocene times. Nature 411:62-66. 